\title{
Bespoke Regulatory Review
}

\author{
BRIDGET C.E. DOOLING* \\ TABLE OF CONTENTS
}

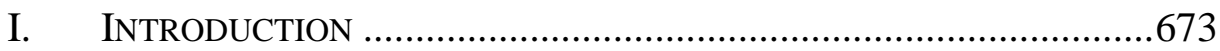

II. THE RISE OF JUDICIAL REVIEW OF REGULATORY ANALYSIS .......674

III. INCREASED RISK FOR INDEPENDENT REGULATORY AGENCIES ....682

A. The Independent Agency ..................................................682

B. Independent Regulatory Agencies and Their Unique

Disadvantage .....................................................................693

IV. FAILED EFForTS TO Change THE StATUS QuO ........................699

A. History of the Exemption from OIRA Review .......................700

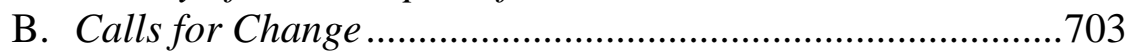

V. BESPOKE REGULATORY REVIEW .............................................707

A. Existing OIRA Review Agreements ...................................708

1. Commodity Futures Trading Commission MOU .............709

2. Internal Revenue Service MOA.....................................712

B. Potential Independent Regulatory Agency MOA

Provisions .................................................................... 713

1. Political Control .........................................................713

2. Dispute Resolution .......................................................715

3. Phase-Ins and Technical Assistance ..............................715

4. Review Process ...........................................................716

5. Transparency ....................................................... 716

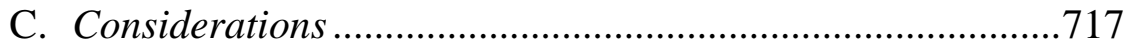

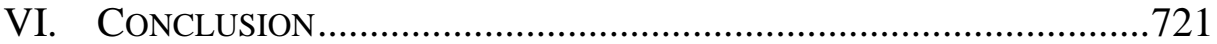

\section{INTRODUCTION}

An agency that fails to adequately consider the costs and benefits of its proposed regulatory changes increasingly places its rules at risk upon judicial review. Over the last couple of decades, courts have begun to expect agencies to use regulatory analysis techniques like cost-benefit analysis to justify their

\footnotetext{
* Bridget C.E. Dooling is a research professor at The George Washington University Regulatory Studies Center. She served as a policy analyst at OIRA from 2007 until 2018. For feedback at various stages of this project, the author thanks her colleagues at the GW Regulatory Studies Center. She also thanks Jennifer Nou, Richard Revesz, and John Cooney, the participants of the Association of American Law Schools (AALS) New Voices in Administrative Law program in January 2019, with particular thanks to Jack M. Beermann, Louis J. Virelli III, Kristin E. Hickman, and Robert B. Ahdieh, and the participants of the Fourth Annual Administrative Law New Scholarship Roundtable hosted by the University of Wisconsin Law School in June 2019 and the AALS annual meeting in January 2020. She also thanks Camille Chambers for research assistance.
} 
regulatory choices. This development poses particularly acute risks for the independent regulatory agencies, because their draft regulations are not reviewed by the Office of Information and Regulatory Affairs (OIRA), the White House experts on cost-benefit analysis who are responsible for executive branch regulatory review. Independent regulatory agencies are taking various steps to improve their regulatory analysis, but none have fully opted in to OIRA's regulatory review, likely because they expect that OIRA review portends the end of their ability to make independent decisions.

But what if it did not? A recent agreement about tax regulations disrupted the conventional understanding about OIRA review, showing that it is not onesize-fits-all and can instead be tailored to suit the unique features of an agency. ${ }^{1}$ "Bespoke" clothing is tailor-made rather than mass-produced. ${ }^{2}$ Bespoke regulatory review, fit to the particulars of each independent regulatory agency, could help remedy regulatory analysis deficiencies at independent regulatory agencies, while also addressing the long-standing legal and political stalemate of OIRA's review of independent regulatory agencies. In Presidential Administration, Elena Kagan described the "energy" and "dynamic charge" that the president can inject into the policymaking process to solve problems. ${ }^{3}$ Bespoke regulatory review, which is an extension of current practice, offers a way to channel this energy to improve regulatory analysis and, therefore, decisions.

Part II summarizes the increased court scrutiny of agency regulatory analysis; a feature of the last two decades. Part III explains why this poses acute risks for the independent regulatory agencies, which do not undergo OIRA review. Part IV shows the flaws of current proposals that call for OIRA's review of independent regulatory agencies. Part V offers the idea of bespoke regulatory review, bilateral memoranda of agreement between OIRA and the independent regulatory agencies, and explains how and why it could work.

\section{THE RISE OF JUdiCIAL REVIEW OF REGULATORY ANALYSIS}

Although it has gone somewhat unnoticed in larger discussions of administrative law and other fields, a well-established line of scholarship has

${ }^{1}$ U.S. DEP'T OF the TREASURY \& OfFICE OF INFO. AND REgUlatory AFFAIRS, Memorandum of AgreEment: The Department of THE TREASURY AND THE OfFice of MANAGEMENT AND Budget REVIEW of TAX REgulations Under EXECUTIVE ORdER 12866, at 1 (Apr. 11, 2018), https://home.treasury.gov/sites/default/files/2018-04/04-11\%20 Signed\%20Treasury\%20OIRA\%20MOA.pdf [https://perma.cc/39VR-JTBK] [hereinafter MEMORANDUM OF AGREEMENT].

2 "Bespoke" means "[a] garment cut by an individual, for an individual" that is "cut from a pattern made specifically for a particular client (i.e. the material is spoken for), whereas a made-to-measure suit is cut from a standard pattern and amended to suit the contours of the individual. The difference is vast." RICHARD WALKER, THE SAVILE ROW STORY 6 (Linda Osband ed., 1988).

${ }^{3}$ Elena Kagan, Presidential Administration, 114 HARV. L. REV. 2245, 2339, 2384 (2001). 
documented the increasing influence of regulatory analysis techniques like costbenefit analysis on judicial review of agency rulemaking, especially over the last two decades. ${ }^{4}$ This has occurred at the Supreme Court and the lower courts, including, but not limited to, the U.S. Court of Appeals for the District of Columbia. ${ }^{5}$ While some have expressed concern about how and whether judges should consider economic analysis in the course of their review, ${ }^{6}$ the fact remains that they are doing so. This shift, which has been taking place at the Supreme Court since 2001, creates new pressure on all rulemaking agencies, but especially the independent regulatory agencies, as will be explained in Part III. This judicial pressure to offer more regulatory analysis creates an opportunity to revisit OIRA's role with respect to these agencies.

In The Cost-Benefit Revolution, Cass R. Sunstein explained that "[t]he number of decisions that scrutinize agency failure to engage in cost-benefit analysis or to give adequate consideration to it is large and growing." ${ }^{77}$ However, this level of scrutiny was not present in 2001. That year, in Whitman v. American Trucking Associations, Inc., ${ }^{8}$ the Court held that Section 109 of the Clean Air Act did not permit the Environmental Protection Agency (EPA) to use cost-

${ }^{4}$ AFL-CIO v. OSHA, 965 F.2d 962, 975 (11th Cir. 1992); Corrosion Proof Fittings v. EPA, 947 F.2d 1201, 1215 (5th Cir. 1991); Reeve Bull \& Jerry Ellig, Judicial Review of Regulatory Impact Analysis: Why Not the Best?, 69 ADMIN. L. REV. 725, 728 (2017) ("Federal courts have increasingly come to view as per se irrational agency action that ignores the economic considerations associated with a contemplated course of action (assuming no statutory prohibition on reviewing such economic considerations exists)."); Caroline Cecot \& W. Kip Viscusi, Judicial Review of Agency Benefit-Cost Analysis, 22 GEO. MASON L. REV. 575, 575-76, 605 (2015) (“Courts are . . increasingly requiring agencies to quantify benefits and costs to the extent possible."); Jonathan S. Masur \& Eric A. Posner, Cost-Benefit Analysis and the Judicial Role, 85 U. CHI. L. REV. 935, 970-76 (2018); Richard L. Revesz, Cost-Benefit Analysis and the Structure of the Administrative State: The Case of Financial Services Regulation, 34 YALE J. ON REG. 545, 547-48 (2017) (“[T]he requirement that the financial regulatory agencies engage in cost-benefit analysis is now likely to become more prevalent."); Catherine M. Sharkey, State Farm "With Teeth": Heightened Judicial Review in the Absence of Executive Oversight, 89 N.Y.U. L. REV. 1589, 1622-30 (2014); Cass R. Sunstein, Cost-Benefit Analysis and Arbitrariness Review, 41 HARV. ENVTL. L. REV. 1, 11 (2017) [hereinafter, Sunstein, Cost-Benefit Analysis]; Christopher Carrigan, Jerry Ellig, \& Zhoudan Xie, Regulatory Impact Analysis and Litigation Risk 5 (Nov. 2019) (unpublished manuscript) (on file with the Ohio State Law Journal). But see Amy Sinden, A 'Cost-Benefit State'? Reports of Its Birth Have Been Greatly Exaggerated, 46 ENVTL. L. REP. 10933, 10934 (2016). See generally Cass R. Sunstein, The Cost-Benefit State (Coase-Sandor Inst. for Law \& Econ., Working Paper No. 39, 1996), https://chicagounbound.uchicago.edu/cgi/ viewcontent.cgi?article=1497\&context=law_and_economics [https://perma.cc/W3FL-2VUL] (tracing this back to Industrial Union Department, AFL-CIO v. American Petroleum Institute, 448 U.S. 607, 610 (1980)).

${ }^{5}$ Sinden, supra note 4 , at 10941-42.

${ }^{6}$ Bull \& Ellig, supra note 4, at 729-30; Cecot \& Viscusi, supra note 4, at 606; Revesz, supra note 4, at 548. But see Sinden, supra note 4, at 10941.

${ }^{7}$ CAss R. Sunstein, The Cost-Benefit Revolution 153 (2018).

${ }^{8}$ Whitman v. Am. Trucking Ass'ns, 531 U.S. 457 (2001). 
benefit analysis to inform its decision about national air quality standards. ${ }^{9}$ The statutory language directed EPA to select the standards based on "such criteria and allowing an adequate margin of safety" that "are requisite to protect the public health." 10 Justice Antonin Scalia, writing for the Court, did not see a clear "textual commitment" to consideration of costs, and declined to read it in. ${ }^{11}$

Justice Scalia changed tack in 2009, writing for the Court in Entergy Corp. v. Riverkeeper, Inc.. ${ }^{12}$ There, the Court allowed the EPA to consider costs and benefits in regulating under Section 316(b) of the Clean Water Act. ${ }^{13}$ The statute directed EPA to issue regulations that "reflect the best technology available for minimizing adverse environmental impact." 14 The Court was persuaded that the "best" technology could be the one that is most efficient, such that it includes consideration of costs. ${ }^{15}$ It continued that "it was well within the bounds of reasonable interpretation for the EPA to conclude that cost-benefit analysis is not categorically forbidden" in setting a standard under the Clean Water Act. ${ }^{16}$ This decision was greeted as a major turning point. One scholar suggested it created "a new presumption for the interpretation of ambiguous ... regulatory provisions on the use of [cost-benefit analysis]." 17 Others agreed, calling it "a shift in Clean Water Act jurisprudence that previously has deemphasized the role of economics." 18

In a somewhat similar vein, the Court decided Environmental Protection Agency v. EME Homer City Generation ${ }^{19}$ in 2014. There, the Court reviewed agency construction of the Good Neighbor Provision of the Clean Air Act. ${ }^{20}$ That provision was silent with regard to cost. ${ }^{21}$ The Court permitted EPA to

\footnotetext{
${ }^{9}$ Id. at 486 .

1042 U.S.C. $\$ 7409$ (b)(1) (2012).

${ }^{11}$ Am. Trucking, 531 U.S. at 468-69. In a concurring opinion, however, Justice Stephen Breyer argued that "other things being equal, we should read silences or ambiguities in the language of regulatory statutes as permitting, not forbidding, this type of rational regulation." $I d$. at 490 (Breyer, J., concurring). He goes on to find that "other things are not equal" in this case, because "legislative history, along with the statute's structure, indicates that $\S 109$ 's language reflects a congressional decision not to delegate to the agency the legal authority to consider economic costs of compliance." Id.

${ }^{12}$ Entergy Corp. v. Riverkeeper, Inc., 556 U.S. 208, 226 (2008).

${ }^{13}$ Id.

1433 U.S.C. $\$ 1326(\mathrm{~b})$ (2012).

15 Riverkeeper, 556 U.S. at 218.

16 Id. at 209.

17 Jonathan Cannon, The Sounds of Silence: Cost-Benefit Canons in Entergy Corp. v. Riverkeeper, Inc., 34 HARV. ENVTL. L. REV. 425, 459 (2010).

18 Paul N. Singarella \& Marc T. Campopiano, The Role of Economics in Environmental, Health, and Safety Regulation After Entergy, 35 ENVIRONS ENVTL. L. \& POL'Y J. 101, 105

${ }^{19}$ EPA v. EME Homer City Generation, 572 U.S. 489 (2014).

${ }^{20} I d$. at $495-96$.

2142 U.S.C. $\$ 7410(a)(2)(D)(i)(2012)$.
} (2011). 
consider cost in construing this provision, with Justice Ruth Bader Ginsburg writing for the Court that the decision to consider costs "makes good sense."22

Building on this reasoning, in 2015 in Michigan v. Environmental Protection Agency ${ }^{23}$ the Court read the phrase "appropriate and necessary" in a section of the Clean Air Act as a statutory mandate requiring EPA to weigh costs against benefits. ${ }^{24}$ Justice Scalia wrote for the majority that "[o]ne would not say that it is even rational, never mind 'appropriate,' to impose billions of dollars in economic costs in return for a few dollars in health or environmental benefits. ... No regulation is 'appropriate' if it does significantly more harm than good." 25 Writing in dissent, Justice Elena Kagan voiced significant support for consideration of benefits and costs in regulatory decision-making: "Cost is almost always a relevant - and usually, a highly important - factor in regulation. Unless Congress provides otherwise, . . . an agency must take costs into account in some manner before imposing significant regulatory burdens." 26 Although Michigan was a 5-4 decision, between Justice Scalia's opinion for the majority, Justice Thomas' concurrence, and Justice Kagan's dissent, "Michigan actually counted nine votes for the principle that costs cannot be ignored."27

Taking these cases together, in ten years, the Court shifted from needing a clear "textual commitment" permitting consideration of costs to finding that a statute that did not mention costs nevertheless required their consideration. ${ }^{28}$ This was, to put it mildly, "a significant evolution." 29 As summarized by Caroline Cecot and W. Kip Viscusi, "it is difficult not to get the impression that

${ }^{22}$ EME Homer City Generation, 572 U.S. at 519.

23 Michigan v. EPA, 135 S. Ct. 2699 (2015).

${ }^{24}$ Id. at 2711-12.

25 Id. at 2707.

${ }^{26}$ Id. at 2716-17 (Kagan, J., dissenting) (citations omitted). This view seems to build on then-Professor Kagan's view of " $[\mathrm{t}]$ he ever-widening appreciation of the role of costbenefit analysis and comparative risk assessment in the formulation of administrative policy." Kagan, supra note 3, at 2353.

${ }^{27}$ EPA, 135 S. Ct. at 2716-17 (Kagan, J., dissenting); Brian F. Mannix, Benefit-Cost Analysis as a Check on Administrative Discretion, 24 SUP. CT. ECON. REV. 155, 157 (2016).

28 The beginnings of the courts' embrace of regulatory analysis and cost-benefit analysis may well run back farther than ten years. Sunstein has written about two influential circuit court decisions. Sunstein, The Cost-Benefit State, supra note 4, at 2 n.5; see AFL-CIO v. OSHA, 965 F.2d 962 (11th Cir. 1992); Corrosion Proof Fittings v. EPA, 947 F.2d 1201 (5th Cir. 1991). In Corrosion Proof Fittings, the U.S. Court of Appeals for the Fifth Circuit held that the Environmental Protection Agency failed to consider alternatives as required by the relevant statute. Corrosion Proof Fittings, 947 F.2d at 1229. In AFL-CIO, the U.S. Court of Appeals for the Eleventh Circuit held that Occupational Safety and Health Commission erred in setting permissible exposure limits for 428 substances without adequate risk-based justification. AFL-CIO, 965 F.2d at 986-87. Similarly, Jonathan S. Masur and Eric A. Posner recently argued that Corrosion Proof Fittings and Business Roundtable were "harbingers of an era of enhanced judicial review of [cost-benefit analysis]." Masur \& Posner, supra note 4, at 970 .

${ }^{29}$ Masur \& Posner, supra note 4, at 975. 
the Court has become more receptive to the use of [benefit-cost analysis] in the thirteen years since American Trucking was decided." 30

The lower courts are on a similar trajectory. The U.S. Court of Appeals for the District of Columbia, which is a specialist on matters of administrative law, ${ }^{31}$ produced a series of decisions involving various regulations from the Securities and Exchange Commission (SEC). ${ }^{32}$ The decisions were written mostly by former OIRA Administrator Judge Douglas Ginsburg and "promot[ed] rigorous [benefit-cost analysis] of financial regulations." 33 Richard L. Revesz tracked this back to 1993 in Timpinaro v. SEC, ${ }^{34}$ in which the court remanded a rule "to address the balance of benefits and costs associated" with it. ${ }^{35}$ Revesz cites the 2005 case of U.S. Chamber of Commerce v. Securities and Exchange Commission ${ }^{36}$ and the 2010 case of American Equity Investment Life Insurance Co. v. Securities and Exchange Commission ${ }^{37}$ in which the court vacated SEC rules on similar grounds. ${ }^{38}$

These cases provided the backdrop for the court's bombshell decision in Business Roundtable v. Securities and Exchange Commission. ${ }^{39}$ There, the court found that a 2010 rule on proxy access was arbitrary and capricious under the Administrative Procedure Act. ${ }^{40}$ In its decision, the court listed SEC's failure to quantify costs as one of several defects in its economic analysis, writing:

We agree with the petitioners and hold the Commission acted arbitrarily and capriciously for having failed once again - as it did most recently in American Equity Investment Life Insurance Company v. SEC ... and before that in Chamber of Commerce...--adequately to assess the economic effects of a new rule. Here the Commission inconsistently and opportunistically framed the costs and benefits of the rule; failed adequately to quantify the certain costs or to explain why those costs could not be quantified; neglected to support its predictive judgments; contradicted itself; and failed to respond to substantial problems raised by

${ }^{30}$ Cecot \& Viscusi, supra note 4 , at 586-87.

${ }^{31}$ See Patricia M. Wald, Harold Leventhal Talk at the District of Columbia Bar: Thirty Years of Administrative Law in the D.C. Circuit (July 1, 1997), https://www.dcbar.org/forlawyers/communities/join-a-community/administrative-law-and-agency-practice/harold-lev enthal-talk-thirty-years-of-administrati [https://perma.cc/F3T9-W6DF].

${ }^{32}$ See generally Robert B. Ahdieh, Reanalyzing Cost-Benefit Analysis: Toward a Framework of Function(s) and Form(s), 88 N.Y.U. L. Rev. 1983 (2013).

${ }^{33}$ Cecot \& Viscusi, supra note 4, at 587.

${ }^{34}$ Timpinaro v. SEC, 2 F.3d 453 (D.C. Cir. 1993) (Ginsburg, J., writing for the court).

${ }^{35} \mathrm{Id}$. at 458; Revesz, supra note 4, at 565.

${ }^{36}$ Chamber of Commerce v. SEC, 412 F.3d 133 (D.C. Cir. 2005) (Ginsburg, J., writing for the court) (vacating for failure to adequately consider costs).

${ }^{37}$ Am. Equity Inv. Life Ins. Co. v. SEC, 613 F.3d 166 (D.C. Cir. 2010) (Sentelle, J., writing for the court) (vacating for failure to adequately consider the rule's effects).

${ }^{38}$ Revesz, supra note 4, at 566-67.

${ }^{39}$ Bus. Roundtable v. SEC, 647 F.3d 1144 (D.C. Cir. 2011) (Ginsburg, J., writing for the court); Catherine M. Sharkey, supra note 4, at 1625-28.

${ }^{40}$ Bus. Roundtable, 647 F.3d at 1144, 1156. 
commenters. For these and other reasons, its decision to apply the rule to investment companies was also arbitrary. ${ }^{41}$

Scholars of financial regulation and administrative law have labored to analyze the meaning and effects of Business Roundtable. ${ }^{42}$ Their response was "swift and furious" for the most part, criticizing the D.C. Circuit for going beyond its appropriate role and interfering with agencies' abilities to achieve their missions. ${ }^{43}$ Most tended to agree that it, at a minimum, "raised the bar for rulemaking for all agencies whose substantive economic analyses could be subject to judicial review." 44 Whether it actually raised the substantive decisionmaking standard for agencies or not, it placed pressure on agencies to produce and share information about economic analysis associated with its regulatory decision-making. ${ }^{45}$ Placing such information into the rulemaking record, in turn, paves the way for its scrutiny upon judicial review.

Ten years after the decision, we can see that Business Roundtable has not, for example, resulted in a dramatic uptick in decisions pushing for quantitative analysis when the record is not there to support it. It may very well be, as some scholars suggested shortly after the decision, ${ }^{46}$ that the holding is cabined to the SEC because of its particular statutory requirements. In support of this ideathat Business Roundtable's holding to require quantification has limited applicability - two recent decisions from the D.C. Circuit show that agency acknowledgement of analytical limits can be viewed favorably by courts.

In Idaho Conservation League v. Wheeler ${ }^{47}$ the petitioners challenged EPA's final rule on financial responsibility requirements for the hardrock

\footnotetext{
${ }^{41}$ Id. at 1148-49 (emphasis added) (citations omitted).

${ }^{4}$ See, e.g., Ahdieh, supra note 32, at 2064-65; John C. Coates IV, Cost-Benefit Analysis of Financial Regulation: Case Studies and Implications, 124 YALE L.J. 882, 91520 (2015); James D. Cox \& Benjamin J.C. Baucom, The Emperor Has No Clothes: Confronting the D.C. Circuit's Usurpation of SEC Rulemaking Authority, 90 TEX. L. REV. 1811, 1833-47 (2012); Grant M. Hayden \& Matthew T. Bodie, The Bizarre Law and Economics of Business Roundtable v. SEC, 38 J. CORP. L. 101, 107-08 (2012); Bruce Kraus \& Connor Raso, Rational Boundaries for SEC Cost-Benefit Analysis, 30 YALE J. ON REG. 289, 290-91 (2013); Yoon-Ho Alex Lee, Essay, An Options Approach to Agency Rulemaking, 65 ADMIN. L. REV. 881, 883-86 (2013); Masur \& Posner, supra note 4, at 96970; Michael E. Murphy, The SEC and the District of Columbia Circuit: The Emergency of a Distinct Standard of Judicial Review, 7 VA. L. \& BUS. REV. 125, 166-69 (2012); Revesz, supra note 4, at 567-68; Sharkey, supra note 4, at 1620-31; Garrett F. Bishop \& Michael A. Coffee, Note, A Tale of Two Commissions: A Compendium of the Cost-Benefit Analysis Requirements Faced by the SEC \& CFTC, 32 REV. BANKING \& FIN. L. 565, 621-24 (2013); Jonathan D. Guynn, Note, The Political Economy of Financial Rulemaking After Business Roundtable, 99 VA. L. REV. 641, 641-42 (2013).

${ }^{43}$ Masur \& Posner, supra note 4, at 963 (discussing the scholarly reaction to Business Roundtable).

${ }^{44}$ Lee, supra note 42 , at 881,885 .

45 Sharkey, supra note 4, at 1646-47.

46 See, e.g., Lee, supra note 42 , at 885-86.

${ }^{47}$ Idaho Conservation League v. Wheeler, 930 F.3d 494 (D.C. Cir. 2019).
} 
mining industry. ${ }^{48}$ The economic analysis was alleged to overstate the costs of the action while "ignoring its health and environmental benefits." 49 The court explained that "[t]he EPA expressly recognized that its estimates" were not built for comparison, which "demonstrates that the EPA did not intend to conduct a rigorous societal cost-benefit analysis," but rather "compared in broad strokes the potential impact" of its rule. 50 The court found that such an approach was reasonable and declined to find EPA's economic analysis arbitrary and capricious. 51

In the same year, the D.C. Circuit decided Mozilla Corp. v. Federal Communications Commission. ${ }^{52}$ In this case, the D.C. Circuit devoted a section of its opinion to reviewing the agency's cost-benefit analysis and reviewed several substantive aspects of the Federal Communications Commission's (FCC) action in light of economic analysis the FCC provided to justify it. ${ }^{53}$ Here, again, the D.C. Circuit looked favorably upon the FCC's self-described limitations of its own analysis. For example, the court supported the FCC's choice to provide qualitative analysis instead of quantitative analysis, particularly when there was inadequate information to support anything more. ${ }^{54}$ Relatedly, "the court approvingly noted how the FCC ... acknowledged the limitations of some of the studies it relied on and was careful not to make excessive claims about what they proved." 55

While some feared that Business Roundtable would raise the bar for agency economic analysis so high that agencies would not be able to clear it, subsequent

${ }^{48}$ Financial Responsibility Requirements Under CERCLA Section 108(b) for Classes of Facilities in the Hardrock Mining Industry, 83 Fed. Reg. 7556, 7556 (Feb. 21, 2018) (to be codified at 40 C.F.R. pt. 320).

${ }^{49}$ Idaho Conservation League, 930 F.3d at 507.

${ }^{50} \mathrm{Id}$. at $507-08$.

51 Id. at 508 .

52 Mozilla Corp. v. FCC, 940 F.3d 1 (D.C. Cir. 2019).

${ }^{53}$ Id. at $70-73$.

${ }^{54}$ Id. at 70 .

[T]he Commission's ultimate decision to conduct a qualitative analysis appears consistent with [OMB Circular A-4]. The latter provides that 'where no quantified information on benefits, costs, and effectiveness can be produced, the regulatory analysis should present a qualitative discussion of the issues and evidence.' The Commission, after finding that 'the record provides little data that would allow [the agency] to quantify the magnitudes of many of' the costs and benefits, adopted the qualitative approach, seeking to assess 'the direction of the effect on economic efficiency.'

Id. (citation omitted).

55 Jerry Ellig, Implications of Mozilla for Agency Economic Analysis, YALE J. ON REG. NOTICE \& COMMENT (Oct. 10, 2019), https://www.yalejreg.com/nc/implications-of-mozillafor-agency-economic-analysis-by-jerry-ellig/ [https://perma.cc/3ME8-K3J5]. 
decisions suggest a more nuanced and limited approach. ${ }^{56}$ Idaho Conservation League and Mozilla suggest that while judges are indeed looking more and more closely at agency cost-benefit analysis, they are not necessarily looking for airtight estimates and demonstrations of certainty. In these two cases, the D.C. Circuit declined to overturn agency action, even though, or perhaps because, the agency acknowledged its analytical limits. The D.C. Circuit's approach should give those concerned about Business Roundtable some comfort.

This interest in reviewing agency cost-benefit analysis is not limited to the D.C. Circuit; other U.S. Courts of Appeals have weighed in as well. A recent study by Cecot and Viscusi reviewed a sample of thirty-eight judicial decisions related to agency cost-benefit analysis. ${ }^{57}$ The sample included cases from ten of thirteen federal appellate courts that "implicate" agency cost-benefit analysis. ${ }^{58}$ Among many other findings, the authors conclude that courts "generally evaluate whether the BCAs include all relevant aspects of the problem, ensuring that entire categories of benefits or costs are not omitted from the analysis." 59 They go on to say that "[c]ourts are... increasingly requiring agencies to quantify benefits and costs to the extent possible." 60

In summary, the Supreme Court and the lower courts have been playing a role in what then-Professor Elena Kagan described in 2001 as "[t]he everwidening appreciation of the role of cost-benefit analysis . . . in the formulation of administrative policy."61 Although opinions are split on how to explain and justify this trend towards the use of economic and other regulatory analysis principles in judicial review, ${ }^{62}$ and, probably, the extent to which it is normatively desirable, scholars do not appear to disagree that it is happening. ${ }^{6} 3$

\footnotetext{
56 See Kraus \& Raso, supra note 42, at 292 (arguing that Business Roundtable v. SEC shows how an "open-ended jurisprudence of economics [in rulemaking] has proven increasingly unworkable in practice").

${ }^{57}$ Cecot \& Viscusi, supra note 4, at 577.

58 See id. at 577, 609-11. The sample did not include cases from the U.S. Courts of Appeals for the Federal Circuit, Eighth, or Third Circuits. See id.

${ }^{59} I d$. at 605 . The acronym BCA refers to benefit-cost analysis, which is an alternative term for cost-benefit analysis.

${ }^{60} \mathrm{Id}$.

${ }^{61}$ Kagan, supra note 3, at 2353.

62 Sunstein argues that the Supreme Court cases discussed above, which were not APA cases, nevertheless suggest that an agency's failure to consider costs and benefits, unless prohibited from doing so by law, should render an agency's decision arbitrary and capricious under the APA. See generally Sunstein, Cost-Benefit Analysis, supra note 4. This argument reads cost-benefit analysis into the APA, which would "make sense of a general trend in the case law that transcends the particular statutes under which the agencies regulate." Masur \& Posner, supra note 4, at 978 . The problem, as noted by Masur and Posner, is that " $[\mathrm{t}]$ here is no textual hook that connects these cases to the APA." Id. at 979. They settle, instead, on the idea that the courts' embrace of cost-benefit analysis is defensible as a form of federal common law. Id.

${ }^{63}$ Bull \& Ellig, supra note 4, at 727-28; Cecot \& Viscusi, supra note 4, at 605 ("Courts are... increasingly requiring agencies to quantify benefits and costs to the extent possible."); Revesz, supra note 4, at 548 ("[T]he requirement that the financial regulatory
} 


\section{INCREASED RISK FOR INDEPENDENT REGULATORY AGENCIES}

Increased judicial scrutiny for the economic underpinnings of regulatory choices poses particular risks for the set of agencies known as the "independent regulatory agencies." To explain why, this section synthesizes recent scholarship revealing that the insulation of independent agencies varies much more than commonly understood, describes the special category known as the "independent regulatory agencies," and explains how those agencies are uniquely disadvantaged compared to others when it comes to regulatory analysis. It is this disadvantage that bespoke regulatory review can help overcome.

\section{A. The Independent Agency}

Independent agencies are a significant portion of the federal government, and while their regulations are just as powerful as those from other agencies, they conduct their business with a measure of political insulation that other agencies do not enjoy. Despite several years of compelling scholarship, the quality of this insulation is generally misunderstood to be binary; an absolute. However, as a class, the independent agencies have greater ambiguity, and failure to recognize this has made them seem untouchable while they are not.

Independent agencies play an important role in the modern regulatory system. Although we lack a precise way to quantify their role, some rough measures give a sense of it. In the Spring 2019 edition of the Semiannual Unified Regulatory Agenda, a forward-looking document listing planned regulatory activity for the coming twelve months, independent agencies expected to contribute around twelve percent of upcoming regulatory actions. ${ }^{64}$ As of 2017 , independent agencies were responsible for about thirteen percent of the "regulatory restrictions" in the Code of Federal Regulations. ${ }^{65}$ These agencies

agencies engage in cost-benefit analysis is now likely to become more prevalent."). But see Sinden, supra note 4, at 10935. Instead, some discussion has focused on whether judges are competent to assess the techniques of regulatory impact analysis, including cost-benefit analysis. Masur \& Posner, supra note 4, at 949 ("The argument against involving judges is based on traditional notions of judicial review: judges, as generalists, are in a weak position to evaluate the work of experts."). Masur and Posner find that judges are capable of such review. Id. at 949-50; accord Cecot \& Viscusi, supra note 4, at 606 ("[O]ur review of thirtyeight cases involving BCA does not demonstrate any inability of the courts to grasp the economic issues, despite the judges' professed lack of expertise.").

${ }^{64}$ About the Unified Agenda, REGINFO.GOV, https://www.reginfo.gov/public/jsp/e Agenda/StaticContent/UA_About.myjsp [https://perma.cc/5THA-HHZY]; Spring 2019 Unified Agenda of Regulatory and Deregulatory Actions, REGINFO.GOV, https://www.reg info.gov/public/do/eAgendaHistory (select "Spring 2019 Unified Agenda of Federal Regulatory and Deregulatory Actions") (calculations on file with author).

65 Jerry Ellig, Why and How Independent Agencies Should Conduct Regulatory Impact Analysis, 28 CoRnell J. L. \& PUB. POL'Y 1, 10 (2018) (using QuantGov data). 
regulate key sectors of the American economy, from consumer products to telecommunications to nuclear power plants. ${ }^{66}$

An agency's independence, or non-independence, has no bearing on its legal authority to promulgate rules. Looking at a rule in the Code of Federal Regulations, a reader might not be able to discern whether it was the product of an independent agency or not. Although the decision-making process might be vastly different at a multimember independent agency or commission, compared to the process at an agency with a single head, ${ }^{67}$ the regulatory output from each type of agency has the same weight as a matter of law. Independent agencies are subject to the Administrative Procedure Act and their rules are proposed in the Federal Register and codified in the Code of Federal Regulations just like those of other agencies. ${ }^{68}$ Judicial review, too, is the same. ${ }^{69}$

The purpose of agency independence, though, is not to ratchet up or down the legal weight of rules based on what kind of agency issues them. Rather, its objective is to insert a layer of political insulation between the agency and the president or other actors that might seek to control the agency's decisionmaking. ${ }^{70}$ The animating idea is that the public as a whole can benefit from a

66 See, e.g., id.

67 See, e.g., Kraus \& Raso, supra note 42, at 336-38 (describing the effects of the Sunshine Act and practice of logrolling at multimember commissions).

68 See Peter L. Strauss, The Place of Agencies in Government: Separation of Powers and the Fourth Branch, 84 COLUM. L. REV. 573, 585 (1984).

${ }^{69}$ Id. ("The Administrative Procedure Act applies equally to all agency types. Case law involving agency procedure, judicial review, or presidential and congressional oversight gives no hint that an agency's 'independence' vel non could be a significant factor in any decision about appropriate or fair procedures."). Some have argued that independent agencies may deserve less deference from the courts, as a result of their disconnection from the president and his policies. See Kagan, supra note 3, at 2375; Sharkey, supra note 4, at $1605,1615-16$.

70 "They are 'independent' of the political will exemplified by the executive branch." Marshall J. Breger \& GARY J. EdLES, IndEPEndENT AgENCIES IN THE United States: LAW, STRUCTURE, AND Politics 2 (2015). Breger and Edles provide an excerpt from the seminal case Humphrey's Executor v. United States to illustrate this theory:

The commission is to be non-partisan; and it must, from the very nature of its duties, act with entire impartiality. It is charged with the enforcement of no policy except the policy of the law. Its duties are neither political nor executive, but predominantly quasijudicial and quasi-legislative .... [I]ts members are called upon to exercise the trained judgment of a body of experts appointed by law and informed by experience ....

[It is] a body of experts who shall gain experience by length of service-a body which shall be independent of executive authority, except in its selection, and free to exercise its judgment without the leave or hindrance of any other official or any department of the government.

Id. at 2 (quoting Humphrey's Ex'r v. United States, 295 U.S. 602, 624, 625-26 (1935) (internal quotation marks and citation omitted) (emphasis omitted)).

In the late nineteenth century and early twentieth century, some of the independent agencies, like the Interstate Commerce Commission, were considered to be "arms of the 
dispassionate, expert decision maker who is insulated from at least some forms of politics. ${ }^{71}$

This is often the argument for the independence of monetary decisions made by the Federal Reserve, for example, because " $[t]$ hough the President and [financial] agencies share a common long-term goal of economic growth, achieving that goal often requires politically unpopular actions in the short term."72 If the president was involved in raising or lowering interest rates, for example, the short-term political consequences of those choices would likely interfere with the Federal Reserve's ability to deliver good long-term outcomes. ${ }^{73}$

While this makes intuitive sense with respect to interest rates, there is agreement that this is a special case. ${ }^{74}$ There is also an extensive literature that explores the constitutional, accountability, and effectiveness problems associated with limiting the president's ability to oversee agency decisionmaking. ${ }^{75}$ Together, this literature undercuts the primary objectives of

Congress" rather than part of the executive branch. Abraham Ribicoff, Congressional Oversight and Regulatory Reform, 28 ADMIN. L. REV. 415, 416 (1976). This claim is not made about modern independent agencies, but the "arms of the Congress" era can be understood to be a legislative "device for opposing the centralization of presidential authority." See Angel Manuel Moreno, Presidential Coordination of the Independent Regulatory Process, 8 ADMIN. L.J. AM. U. 461, 467 (1994) (quoting MARVER H. BERNSTEIN, REGULATING BUSINESS BY INDEPENDENT COMMISSION 151 (1955)).

${ }^{71}$ See Rachel E. Barkow, Insulating Agencies: Avoiding Capture Through Institutional Design, 89 TEX. L. REV. 15, 19-21 (2010). Also, it is not only insulation from the president that matters. Rachel Barkow wrote that "one cannot begin to think about what makes an agency independent without thinking about what the agency is supposed to be independent of." Id. at 19. Options include not just the President and Congress, but also special interests that can outmaneuver the more diffuse interests of the general public due to collective action problems. Id. at 16-17, 22-24.

72 Id. at 29.

73 See Steven G. Calabresi \& Nicholas Terrell, The Fatally Flawed Theory of the Unbundled Executive, 93 MINN. L. REV. 1696, 1717 (2009) (noting that "[a] nationally elected Federal Reserve Board, for example, might well choose to manipulate interest rates to enhance its own reelection chances"). Sarah Binder and Mark Spindel dispute the notion that even the Fed is truly independent, however, describing the Fed and Congress "interdependent" instead. SARAH BINDER \& MARK SPINDEL, THE MYTH OF INDEPENDENCE: How CONGRESS GOVERnS THE FEDERAL RESERVE 2 (2017).

${ }^{74}$ See, e.g., Peter Conti-Brown, The Institutions of Federal Reserve Independence, 32 YALE J. ON REG. 257, 264-65 (2015); Lawrence Lessig \& Cass R. Sunstein, The President and the Administration, 94 COLUM. L. REV. 2, 108 (1994) (arguing that EPA's mission is categorically different from the Fed's).

${ }^{75}$ First, with regard to constitutionality, proponents of the unitary executive theory view the executive branch hierarchically, with the president at the top and the independent agencies below. See Neomi Rao, Removal: Necessary and Sufficient for Presidential Control, 65 AlA. L. REV. 1205, 1207 n.7 (2014). See generally STEVEN G. CALABRESI \& Christopher S. Yoo, The Unitary Executive: Presidential Power From WASHington TO BUSH (2008). 
independent agencies, and therefore calls them into question. Perhaps as a result, there have been waves of interest in the study and reform of independent agencies. ${ }^{76}$ Despite periodic efforts to curtail independent agencies, Congress sporadically turns to the independent agency model when it creates new agencies. ${ }^{77}$ From $1887^{78}$ onward, and as recently as $2010,{ }^{79}$ when Congress has delegated a new set of regulatory powers, it has placed those responsibilities into agencies with differing levels of insulation from executive and legislative control. ${ }^{80}$

The specific reasons why Congress, on occasion, places authority into independent agencies as opposed to others are not always clear or consistent: "New agency structures often appear to be created in a vacuum or almost by

Second, one does not have to hold the unitary executive view of government to be concerned about the political accountability of independent agencies. The results of presidential elections transmit much less directly to independent agencies, because the tenure of their heads are generally not tied to any president's term; unlike the heads of the Cabinet agencies, for example. How, then, are independent agencies accountable to the people, especially if they also have some insulation from Congress? See Heidi Kitrosser, The Accountable Executive, 93. MINN. L. REV. 1741, 1751-60 (2009) (discussing three types of accountability); see also Calabresi \& Terrell, supra note 73, at 1722-23 (discussing the role of accountability in the executive branch). Rachel Barkow astutely notes the trade-offs of political insulation: “one person's political pressure is another person's democratic accountability." Barkow, supra note 71, at 19. The merits of relieving agency leadership from political accountability are contestable.

Third, turning to effectiveness, as an experiment in "expert, apolitical" government, the independent agency model was not successful, as "by the 1960s, it became clear that [independent] agencies faced the same pathologies, such as capture and poor decision making, as executive agencies." Kirti Datla \& Richard L. Revesz, Deconstructing Independent Agencies (and Executive Agencies), 98 CORNELL L. REV. 769, 771 (2013); see also BREGER \& EDLES, supra note 70, at 56-57 (describing the shift from reliance upon agency expertise to awareness of interest group bargaining); Calabresi \& Terrell, supra note 73, at 1703 ("As we have learned more about the capture of independent regulatory commissions and as public choice scholarship has come to prevail, belief in 'independent' government entities has come to seem like . . . a 'fable.' Today, we realize how easy it is for special-interest groups and factions to capture the so-called independent regulatory agencies just as it is easy for them to capture the oversight committees.") (footnotes omitted).

76 See Moreno, supra note 70, at 481-88 (summarizing historical developments).

77 See Datla \& Revesz, supra note 75, at 776-80.

${ }^{78}$ Interstate Commerce Act of 1887, ch. 104, §§ 11, 21, 24 Stat. 379, 383, 387 (1887) (codified as amended in scattered sections of 47 U.S.C.); BREGER \& EDLES, supra note 70, at 31-32 (summarizing the creation of the Interstate Commerce Commission in 1887).

${ }^{79}$ In 2010, Congress created the Consumer Financial Protection Bureau. Dodd-Frank Wall Street Reform and Consumer Protection Act, Pub. L. No. 111-203, § 1011(a), 124 Stat. 1376, 1964 (2010).

${ }^{80}$ See Patrick M. Corrigan \& Richard L. Revesz, The Genesis of Independent Agencies, 92 N.Y.U. L. REV. 637, 643-44 (2017) (finding statistical significance of three factors related to creation of agencies with independent features: presidential approval rating, extent of majority in the Senate, and alignment between the Senate and the president, but also acknowledging the limited explanatory power of these factors). 
random selection." 81 Perhaps more generously: "The diversity is characteristic of our pragmatic ways with government, reflecting the circumstances of the particular regulatory regime, the temper of presidential/congressional relations at the time, or the perceived success or failure of an existing agency performing like functions, more than any grand scheme of government." 82

Insulation can take a variety of forms. ${ }^{83}$ For example, it can protect an agency's decisionmakers from influence, through removal protections and appointment restrictions. ${ }^{84}$ It can also exempt an agency from the policy processes to which other agencies are subject. ${ }^{85}$ There are dozens of different features that can inform an agency's independence. ${ }^{86}$

Limits to the president's ability to remove an agency head is considered to be the most important of these features. ${ }^{87}$ Requiring good cause to remove an

${ }^{81}$ Paul R. Verkuil, The Purposes and Limits of Independent Agencies, 1988 DUKE L.J. 257,258 . "What is lacking in the creation of independent agencies is any attempt in the legislative history to explain why Congress (or the President, for that matter) preferred one organizational format over the other." $I d$.

${ }^{82}$ Strauss, supra note 68, at 584-85; see also DAVID E. LEWIS \& JENNIFER L. SELIN, AdMIN. CONFERENCE OF THE U.S., SOURCEBOOK OF UNITED STATES EXECUTIVE AGENCIES 34 (1st ed. Dec. 2012), https://www.acus.gov/sites/default/files/documents/Sourcebook2012-Final_12-Dec_Online.pdf [https://perma.cc/A22F-6Q2H] [hereinafter LEWIS \& SELIN, SOURCEBOOK] (noting that the "status and location of agencies is the subject of political determination" and the absence of a consciously executed "fundamental constitutional or management principle"); Datla \& Revesz, supra note 75, at 770-72, 776-78 (summarizing the ebb and flow of interest in agency independence); David E. Lewis \& Jennifer L. Selin, Political Control and the Forms of Agency Independence, 83 GEO. WASH. L. REV. 1487, 1490 (2015) [hereinafter Lewis \& Selin, Political Control] ("[C]hoices of insulation are not always based upon high-minded efforts associated with quasi-legislative or quasi-judicial activities. Indeed, sometimes the only way a legislative deal gets made to enact a new policy is when legislators agree to create a new insulated agency to implement the policy. In a less rosy version of the politics of agency design, opponents of a new proposed policy insist on provisions in the new law that privilege some interests over others and limit the ability of political actors to intervene.").

${ }^{83}$ See Barkow, supra note 71, at 42-49; Jennifer L. Selin, What Makes an Agency Independent?, 59 AM. J. POL. SCI. 971, 971 (2015), http://publish.illinois.edu/jselin/files/ 2014/07/SelinIndepCodebook.pdf [https://perma.cc/NBM9-YKHD] [hereinafter Selin, What Makes an Agency Independent?]. See generally Datla \& Revesz, supra note 75.

${ }^{84}$ Lewis \& Selin, Political Control, supra note 82, at 1508.

$85 \mathrm{Id}$.

${ }^{86}$ Selin, supra note 83, at 976 (discussing fifty structural features of agencies that combine for more or less independence). There are more subtle authorities that could be mapped as well, such as inclusion or exclusion from government-wide procurement policies, personnel policy, grants policy, etc. See, e.g., Strauss, supra note 68, at 587.

${ }^{87}$ LEWIS \& SELIN, SOURCEBOOK, supra note 82, at 49 n. 133 ("Most existing scholarship recognizes some clustering of design characteristics that together signify independence, but the most important characteristic appears to be protections against removal."); Lisa Schultz Bressman \& Robert B. Thompson, The Future of Agency Independence, 63 VAND. L. REV. 599, 610 (2010) (explaining that while independent agencies can have various unique attributes and features, for-cause removal strips the president of the "ultimate sanction" to direct agency behavior). 
official places a strong check on the president's ability to influence that official. ${ }^{88}$ Surprisingly, though, some independent agencies lack statutory removal protection, most notably the Federal Communications Commission (FCC) and Securities and Exchange Commission (SEC). ${ }^{89}$ Instead, Wiener v. United States grants them implied for cause removal protections. ${ }^{90}$ And the

88 The power to remove is an "indispensable aid" to "effective enforcement of the law" due to its "disciplinary influence." Myers v. United States, 272 U.S. 52, 132 (1926). "[I]t is quite evident that one who holds his office only during the pleasure of another, cannot be depended upon to maintain an attitude of independence against the latter's will." Humphrey's Ex'r v. United States, 295 U.S. 602, 629 (1935).

Removal protections are varied in form (e.g., "inefficiency, neglect of duty, or malfeasance in office"), but they operate in stark contrast to those positions without them, whose occupants serve at the pleasure of the president and can be removed for any reason. See Myers, 272 U.S. at 171; Datla \& Revesz, supra note 75, at 787-89 (describing the variety of removal provisions); see also Neal Devins, Political Will and the Unitary Executive: What Makes an Independent Agency Independent?, 15 CARDOZO L. REV. 273, 278 (1993) (noting that removal protections allow agency heads to be "secure in their offices" and "better able to defy [e]xecutive wishes and assert independent authority"); Richard H. Pildes \& Cass R. Sunstein, Reinventing the Regulatory State, 62 U. CHI. L. REV. 1, 25 (1995) (describing that an agency head risks his job by defying the president and therefore has an incentive to comply with the president). The practical power of removal can be overstated, though. See, e.g., Datla \& Revesz, supra note 75, at 813 (describing political cost to the president of removing agency heads); Kagan, supra note 3, at 2273 (describing the surveillance costs of supervision).

${ }^{89}$ Communications Act of 1934, ch. 651, § 4, 48 Stat. 1064, 1066 (1934) (codified as amended at 47 U.S.C. $\$ 151$ ) (establishing the structure of the FCC); see also Adrian Vermeule, Conventions of Agency Independence, 113 CoLuM. L. REV. 1163, 1165-66, 1168-74 (2013) (describing more examples of "independent" agencies without for cause removal). See generally Note, The SEC Is Not an Independent Agency, 126 HARV. L. REV. 781 (2013).

${ }^{90}$ Wiener v. United States, 357 U.S. 349, 356 (1958). In Wiener, the Supreme Court considered whether the head of the now-defunct War Claims Commission was removed unlawfully. Id. The statute that created the commission did not have a removal provision. Id. at 350. The Court held that some agencies enjoy "absolute freedom from Executive interference," as a result of the "sharp line of cleavage" drawn on the basis of removal protections. Id. at 353. It then considered the functions of the War Claims Commission and, finding similarities to the Federal Trade Commission, which has for cause removal protections, implied for cause removal limitations for the War Claims Commission as well. Id. at 353-54.

Writing in 1980, Paul Verkuil correctly foresaw the likelihood that this holding would be extended to other agencies. Paul R. Verkuil, Jawboning Administrative Agencies: Ex Parte Contacts by the White House, 80 CoLUM. L. REV. 943, 954 n.65 (1980) (noting that the holding in Wiener $v$. United States presumably extends to other independent agencies without explicit for-cause removal protection). Later, and at the behest of agencies arguing for protection, both the D.C. Circuit and the U.S. Court of Appeals for the Tenth Circuit found for-cause removal protection at the Securities and Exchange Commission and Federal Election Commission. SEC v. Blinder, Robinson \& Co., 855 F.2d 677, 681 (10th Cir. 1988) ("[The court] accept[s] appellants' assertions in their brief, that it is commonly understood that the President may remove a commissioner only for 'inefficiency, neglect of duty or malfeasance in office.”); Datla \& Revesz, supra note 75, at 778-81, 779 n.52 (citing FEC v. 
presence of an insulating feature can be just as surprising as its absence. For example, the head of the Social Security Administration, which is generally not considered to be independent, has for cause removal protection. ${ }^{91}$ In sum, it is simply not the case that even this most powerful form of insulation-removaloffers a clear, dividing line between "independent" and "not independent."

And this uneven distribution of insulating features is not limited to removal protections. ${ }^{92}$ Variation occurs with appointment restrictions, such as the choice to organize agencies into multimember bodies ${ }^{93}$ with fixed, staggered terms ${ }^{94}$ and other composition limits of varying kinds. ${ }^{95}$ It also occurs with various forms of insulation for agency decision-making, such as budget ${ }^{96}$ and other

NRA Political Victory Fund, 6 F.3d 821, 826 (D.C. Cir. 1993)) ("The commission suggests that the President can remove the commissioners only for good cause, which limitation is implied by the Commission's structure and mission as well as the commissioners' terms."). The argument in these appeals court decisions has been that, even if Congress did not expressly say that an agency head is entitled to removal protections, one can imply such protections if the agency is otherwise similar to agencies with removal protections. In essence, "omission of a for-cause removal protection provision must have been a drafting error." Datla \& Revesz, supra note 75, at 780. Datla and Revesz argue persuasively that Wiener and the cases that followed "were incorrectly decided because their central premisethat the presence of certain features of independence is evidence of congressional intent to endow an agency with other features of independence - is wrong." Id. at 833.

9142 U.S.C. $\$ 902(a)(3)$ (2012).

${ }^{92}$ For an excellent and comprehensive survey of the distribution of these different features, consult Jennifer Selin's excellent resource, the Independent Agency Codebook, which she makes freely available. See generally Selin, What Makes an Agency Independent?, supra note 83.

93 See Bressman \& Thompson, supra note 87, at 611 (“'[T] he collective-board structure inhibits political control because politicians or regulated entities must capture a majority of the membership rather than just one individual."); Datla \& Revesz, supra note 75, at 79497.

94 See Datla \& Revesz, supra note 75, at 789-92.

95 See Bressman \& Thompson, supra note 87, at 611 ("[T] of independent agencies represent both political parties is an overt attempt at achieving political balance.”); Datla \& Revesz, supra note 75, at 797-99. Other limitations seemed aimed at diversity, as well. The Federal Reserve requires geographic and sectoral diversity. LEWIS \& SElin, SOURCEBOOK, supra note 82, at 103 (Table 8); Bressman \& Thompson, supra note 87 , at 610-11. Presidents sometimes appoint cabinet secretaries from other political parties, but this is the exception, not the rule, and is done at the president's discretion. Bressman \& Thompson, supra note 87, at 610-11.

96 The federal budget process culminates in the annual President's Budget, a transmission to Congress that informs annual appropriations bills. See generally Eloise Pasachoff, The President's Budget as a Source of Agency Policy Control, 125 YALE L.J. 2182 (2016). But some agencies have the authority to raise a substantial portion of their operating budget through fees and other mechanisms that do not rely on presidential budgeting or Congressional appropriations. This can disconnect the agency from presidential oversight as well as Congressional appropriations. See Conti-Brown, supra note 74, at 27374 (discussing the Federal Reserve's budgetary independence). 
funding decisions, ${ }^{97}$ choices about how and whether to support new legislation or proposed statutory reforms and how to communicate views to Congress, ${ }^{98}$ and how and whether to litigate. ${ }^{99}$ The result is various and inconsistently-

\footnotetext{
97 Some agencies can communicate directly with Congress to negotiate their budgets rather than relying on the president's consolidated budget request. Under current law, agencies must coordinate their budget requests through OMB, unless they are carved out. Office of Mgmt. \& Budget, Exec. OfFice of the President, OMB Circular No. A$11 \S 10.5$ (July 2020); see Memorandum from Jim Jukes, Assistant Dir. for Legislative Reference, to OMB Policy Officers and DADs 2-6 (Feb. 20, 2001), https://www.citizen.org/ sites/default/files/ombdocument1.pdf [https://perma.cc/Z7LT-MM2Z] [hereinafter Jukes Memorandum]. An agency might prefer to communicate with Congress about its budgetary matters to better influence the outcome by advocating more directly for its preferences without consideration of presidential preferences or what other agencies are requesting. See Strauss, supra note 68, at 591-92. While this provides flexibility, evidence is not clear that this ultimately benefits these agencies. See Datla \& Revesz, supra note 75, at 806 n.207 (citing Kenneth J. Meier, The Impact of Regulatory Organization Structure: IRCs or DRAs?, 3 S. ReV. PuB. Admin. 427, 438 (1980) and Christopher G. Reddick, IRCs Versus DRAs: Budgetary Support for Economic and Social Regulation, 23 PUB. BUDGETING \& FIN. 21, 4748 (2003) for the proposition that agencies with budget bypass secure lower funding increases than other agencies coordinated by the president's budget process).

98 Most agencies are expected to coordinate legislative communications through OMB, but some can communicate directly with Congress about legislative business. See generally OfFice of Mgmt. \& Budget, Exec. OfFice of the President, OMB Circular No. A-19 (Sept. 1979). As Richard Neustadt noted: "Here is presidential machinery to coordinate a vital aspect of executive policy development; machinery to control, in some degree at least, the means by which the diverse elements of the executive express and implement their own designs." Richard E. Neustadt, Presidency and Legislation: The Growth of Central Clearance, 48 AM. POL. SCI. REV. 641, 642 (1954). This system of review and clearance has been part of OMB since the 1920s. Id. OMB keeps a "tight reign" on the process. David E. Lewis, The Adverse Consequences of the Politics of Agency Design for Presidential Management in the United States: The Relative Durability of Insulated Agencies, 34 BRIT. J. POL. SCI. 377, 389 (2004). Bypassing this program can be valuable to an agency because it allows pursuit of the agency's own agenda, without first coordinating with the rest of the executive branch and perhaps compromising on its views. OMB maintains a list of exceptions. See generally Jukes Memorandum, supra note 97. It explains:
}

These legislative bypass provisions undermine the President's role as Chief Executive and can deprive the President, Executive agencies, and Congress of the full benefits of OMB's central clearance process. In particular, OMB's coordination of legislative proposals, testimony, and the like on behalf of the Administration serves several important purposes. First, it provides a mechanism for development of a coherent legislative program for the President. Second, it encourages the various agencies to take the concerns and views of other agencies into account. Third, it facilitates the development of a consistent Administration position on legislation. Finally, it assures that Congress gets coordinated and informative agency views on legislation under consideration.

Id. at 2 .

99 Some agencies can represent themselves in court, while others must rely on the Department of Justice to be their advocates. Neal Devins \& Michael Herz, The Uneasy Case for Department of Justice Control of Federal Litigation, 5 U. PA. J. ConsT. L. 558, 559-61 
distributed authorities that allow some agencies to make their own choices in certain areas but not others. In each case, from the standpoint of institutional design and incentives facing the agencies, the benefits of individual agency flexibility trade off against the benefits of coordinated action across the executive branch, among other considerations.

The uneven distribution of removal protections, other structural features, and decision-making authorities sits in opposition to the conventional understanding that certain agencies are independent and others are not. ${ }^{100}$ Instead, a "fluid and slippery thing," 101 independence is not a single quality that an agency either does or does not durably possess. ${ }^{102}$ The binary view that an

(2003). See generally Margaret H. Lemos, The Solicitor General as Mediator Between Court and Agency, 2009 MICH. ST. L. REV. 185; Susan M. Olson, Challenges to the Gatekeeper: The Debate Over Federal Litigating Authority, 68 JUDICATURE 71 (1984); Bijal Shah, Executive (Agency) Administration, 72 STAN. L. REV. 641 (2020). Congress has enacted many exceptions, most of which are limited in some way to particular actions or venues. Datla \& Revesz, supra note 75, at 799-804; Neal Devins \& Michael Herz, The Battle That Never Was: Congress, the White House, and Agency Litigation Authority, 61 L. \& CONTEMP. PROBS. 205, 208 (1998).

Litigation bypass gives an agency the ability to choose which cases to initiate or appeal, as well as which arguments to make in enforcement or defensive litigation. See Neal Devins, Unitariness and Independence: Solicitor General Control over Independent Agency Litigation, 82 CALIF. L. REV. 255, 256 (1994) [hereinafter Devins, Unitariness and Independence]; Alan B. Morrison, How Independent Are Independent Regulatory Agencies?, 1988 DUKE L.J. 252, 254-55 (discussing DOJ litigation review for independent agencies). One example of the significance of this bypass is that it sidesteps appellate review from the Solicitor General's office, which bears the burden of coordinating positions taken by the U.S. government before the Supreme Court. See Devins, Unitariness and Independence, supra, at 256. Factors unrelated to an agency might inform the Solicitor General's preferences on that agency's litigation strategy, because of the desire to present a unified position. See Datla \& Revesz, supra note 75 , at 802 . The choice to pursue or forgo an appeal can influence or even bind future decision-making. See id. One example is the decision of whether to appeal a court's decision after a loss. Absent an appeal, the agency might reasonably be concerned that it is in a weaker position on future, similar issues. See $i d$. There is also emerging study of intra-executive branch litigation, i.e., agencies suing each other, suggesting that one agency's ability to initiate its own suits against another agency is valuable. See generally Shah, supra.

100 See Vermeule, supra note 89, at 1165-66; see also Datla \& Revesz, supra note 75, at 772; Selin, supra note 83 , at 972-73. Those seeking a clean line between these two categories in the modern administrative state have not found it. See BREGER \& EDLES, supra note 70, at 4 ('Our definition of 'independent' is somewhat arbitrary, but the lack of both doctrinal cohesion and comprehensive information makes the task of definition difficult."); LEWIS \& SELIN, SOURCEBOOK, supra note 82, at 48-65.

101 Devins, supra note 88 , at 312.

102 See Bressman \& Thompson, supra note 87, at 600-01 (describing mechanisms for "presidential involvement short of plenary control" and challenging the "binary division" between independent and executive agencies); see also Datla \& Revesz, supra note 75, at 772; Morrison, supra note 99, at 256 (stating that some independent agencies "are neither as dependent nor as independent as they sometimes seem, and the situation seems likely to continue that way for some time"). Agencies that are understood to be "independent" do not 
agency is either independent or not independent is what Anne Joseph O'Connell has called a "cramped view of the administrative state." 103 A binary distinction papers over the statutory variation of agencies and the "body of observed practices and norms that constitute the landscape of agency independence."104 Once the binary is peeled away, what emerges is a sort of manifest independence for each agency. ${ }^{105}$ Datla and Revesz have argued that agency independence exists along a continuum, with some agencies possessing greater claim to independence than others. ${ }^{106}$ They include, on this continuum, agencies generally described as "executive" agencies, demonstrating that even those agencies can have certain features that insulate them from presidential control. ${ }^{107}$

A second set of scholarly insights shows that there is a temporal dimension as well. Selin and Lewis show that agency independence changes over time, particularly in the ways that agency decision making gains insulation from political review over time. ${ }^{108}$ O'Connell's work gives the frame of centrifugal and centripetal movement away from - or towards - the president's political control. ${ }^{109}$ Focusing on the Federal Reserve, Peter Conti-Brown documents the

even necessarily have that term in their enabling statutes. E.g., 15 U.S.C. $§ 41$ (2012) (enabling act for the Federal Trade Commission).

103 Anne Joseph O'Connell, Bureaucracy at the Boundary, 162 U. PA. L. REV. 841, 922 (2014). In this article, O'Connell considers vertical dimensions of political control, "between federal and state actors or federal and foreign players, as well as on other dimensions that drive agency structure." Id.

104 See Vermeule, supra note 89 , at 1174.

105 See LeWIS \& SELIN, SOURCEBOOK, supra note 82, at 49 n.133 ("Most existing scholarship recognizes some clustering of design characteristics that together signify independence ....").

106 Datla \& Revesz, supra note 75, at 772-73; accord Lewis \& Selin, Political Control, supra note 82, at 1504-05 ("Because so many features affect responsiveness, agency independence should be thought of as a scale, ranging from less to more insulated from political influence. Most independent agencies have many structural features that insulate them from political control and are located on one end of this scale.").

107 Datla \& Revesz, supra note 75, at 826. Additional painstaking, empirical work from the political science literature bears this out. In 2015, Jennifer Selin published her analysis of 321 federal agencies, examining fifty different features in an effort to estimate independence. Selin, supra note 83, at 976. Selin's work provides methodological rigor to the realization that agency independence is far more complex than the question of for-cause removal, and that control over agency policymaking processes can be just as important as the features that determine who leads the agency. Id. at 972. Selin estimated "structural independence" across two dimensions: independence of decision makers and independence of policy decisions. $I d$. The former includes elements like for-cause removal and term length requirements. $I d$. The latter includes elements like whether agencies can communicate with Congress without prior review from others in the executive branch. Id. Her work shows the agencies mapped on these two dimensions, revealing, for example, that the Federal Reserve Board of Governors exhibits the most independence while Cabinet agencies have the least independence. $I d$. at 980.

108 Lewis \& Selin, Political Control, supra note 82, at 1512.

109 O'Connell, supra note 103, at 871-74. 
rise of its independence over time. ${ }^{110}$ Conti-Brown argues that the Fed's increased independence is only partly due to statutory grants of independence. ${ }^{111}$ Instead, he explains that "the laws of Federal Reserve independence demonstrate the iterative, interactive conversation between formal law, modern practice, and historical change." 112 Such dynamism defies formalist, binary approaches to understanding agency independence.

Neil Devins' theory of political will helps explain how an agency might manage to assert independence in an area that was not expressly granted to it by Congress, and how a president might erode an agency's independence. He explains that "[s]tructural limitations are significant, but not controlling. The willfulness of the President, the Congress, and the agency itself are equally important."113 He uses the Equal Employment Opportunity Commission (EEOC) as an example of political dynamism that can diminish an agency's independence, showing that Justice Department control over EEOC litigation, followed by Congressional acquiescence, brought the EEOC to heel. ${ }^{114}$ In the other direction, he documents the increasing independence of the FCC due to "[c]ongressional and agency assertions of power."115

Devins' theory offers a frame through which to consider individual developments such as the FTC's attempt to break away from the president's budget process, ${ }^{116}$ or the various assertions of agencies that they need not comply with OMB's legislative review program, ${ }^{117}$ and so on. These are merely efforts to break away from executive control. The reciprocal notion that the president seeks to maximize control in all instances might also be oversold. ${ }^{118}$ The president might abide agency assertions of control if the president is able to get what he or she wants through other forms of presidential influence, such as the power to appoint members, select the agency's chair, use the ability to

110 See generally Peter Conti-Brown, supra note 74.

111 Id. at $259-60$.

112 Id. at 261.

113 Devins, supra note 88, at 274.

114 Id. at $273,285-98$.

115 Id. at 274-75, 298-306.

116 Datla \& Revesz, supra note 75 , at 780.

117 OMB Circular A-19 defines an "agency" broadly as "[a]ny executive department or independent commission, board, bureau, office, agency, Government-owned or controlled corporation, or other establishment of the Government, including any regulatory commission or board and also the municipal government of the District of Columbia." OFFICE OF MGMT. \& Budget, ExeC. OfFice OF THE PRESIDENT, OMB CirCular No. A-19 § 5(b) (Sept. 1979). Under this definition, independent agencies are included. It does include a carve-out for "those agencies that are specifically required by law to transmit their legislative proposals, reports, or testimony to the Congress without prior clearance.” Id. $\S 4$. It goes on to note, though, that OMB will "honor requests from such agencies for advice on the relationship of particular legislation, reports, or testimony to the program of the President." Id.

118 Bressman \& Thomson, supra note 87, at 601 ("[T] a political interest in seeking maximum control of regulatory policy."). 
remove for cause when appropriate, and other, informal techniques such as "jawboning" to influence decision-making at the agency. ${ }^{119}$

This scholarship is helpful to explain why independence fails to be an allor-nothing designation, and why it may shift over time. Most importantly for this article, it is clear that insulating features are neither uniformly distributed across independent agencies nor entirely withheld from non-independent agencies, and that this can change over time as political will waxes and wanes. The "natural conclusion" of this revelation "is that independence is unstable as a legal category." 120 Datla and Revesz explain that a "constitutional force field" generally surrounds independent agencies, but that this is flawed reasoning arising from the binary view of agency independence. ${ }^{121}$ They argue that "the diversity of agency form should affect the way we think about agencies" and that " $[t]$ here is no reason to believe that Congress means for agencies to have special constitutional protection from presidential control when it chooses not to grant those same agencies full or uniform statutory protection against such control." 122

The consequences of categorical distinctions despite extant ambiguity include errors of over- or under-inclusion, or in the case of agency independence, over- or under-insulation. Policies that grant independent agencies special immunity can erroneously overextend political insulation. The error can flow the other direction, too, with inadequate deference from the president. Both errors are borne of the same mistaken understanding of the true nature of agency independence.

\section{B. Independent Regulatory Agencies and Their Unique Disadvantage}

The remainder of this article will focus on a subset of independent agencies called the "independent regulatory agencies." This is the set of agencies that are exempt from the regulatory review conducted by the OIRA under Executive Order (EO) 12,866. ${ }^{123}$ Given the rise of judicial review of regulatory analysis, the independent regulatory agencies are uniquely disadvantaged upon judicial review.

Most federal agencies are subject to EO 12,866, the order that has governed regulatory review since $1993 .{ }^{124}$ It directs agencies to conduct certain analyses

119 See generally Verkuil, supra note 90. Verkuil describes "jawboning" as the phenomenon when "the President may have the power to act directly, but he prefers for political reasons to cajole, persuade, or arbitrate." Id. at 943.

120 Vermeule, supra note 89, at $1181 \mathrm{n} .83$ (arguing also that independence might be "best understood as a conventional rather than legal attribute").

121 Datla \& Revesz, supra note 75 , at 773.

122 Id. at $773-74$.

123 Exec. Order No. 12,866, 58 Fed. Reg. 51,735 (Sept. 30, 1993).

124 Id. 
of their proposed regulatory changes and to submit those materials to OIRA for review prior to publication. ${ }^{125}$

The literature on OIRA review is vast and the office has been controversial since it was created. OIRA is the poster-child of what then-Professor Elena Kagan termed "presidential administration," an instrument for the president to influence agency regulatory processes. ${ }^{126}$ As such, OIRA-"a mixture of expertise and politics" 127 _has been a lightning rod in the debate over the proper role of the president in policymaking, the limits and promise of analytical techniques used to assess proposed rule changes, and the expanding bureaucracy itself. ${ }^{128}$ Despite these controversies, the office has endured; a sign of its usefulness to presidents of both parties.

As many have described, OIRA review serves multiple functions, including technical assessment against OMB standards for regulatory analysis (e.g., costbenefit analysis), interagency coordination across the executive branch, and political review. First, the standards for regulatory analysis are meant to infuse agency decision-making with analytic rigor. EO 12,866 contains a "regulatory philosophy" that

Federal agencies should promulgate only such regulations as are required by law, are necessary to interpret the law, or are made necessary by compelling public need, such as material failures of private markets to protect or improve the health and safety of the public, the environment, or the well-being of the American people. In deciding whether and how to regulate, agencies should assess all costs and benefits of available regulatory alternatives, including the alternative of not regulating. Costs and benefits shall be understood to include both quantifiable measures (to the fullest extent that these can be usefully estimated) and qualitative measures of costs and benefits that are difficult to quantify, but nevertheless essential to consider. Further, in choosing among alternative regulatory approaches, agencies should select those approaches that maximize net benefits (including potential economic, environmental, public health and safety, and other advantages; distributive impacts; and equity), unless a statute requires another regulatory approach. ${ }^{129}$

125 Id. Exactly what happens during OIRA review is the subject of much curiosity, speculation, and concern. See, e.g., Lisa Heinzerling, Statutory Interpretation in the Era of OIRA, 33 FORDHAM URB. L.J. 1097, 1097 (2006). Former OIRA insiders have tried to shine a light on the office, but there is more work to be done. See, e.g., Stuart Shapiro, OIRA Inside and Out, 63 Admin. L. REV. 135, 136 (2011); Cass R. Sunstein, Commentary, The Office of Information and Regulatory Affairs: Myths and Realities, 126 HARV. L. REV. 1838, 1838 (2013).

126 Kagan, supra note 3, at 2246.

127 Susan Rose-Ackerman, Putting Cost-Benefit Analysis in Its Place: Rethinking Regulatory Review, 65 U. MiAmi L. REV. 335, 340 (2011).

128 See Carrigan, Ellig, \& Xie, supra note 4, at 12 (discussing impact analysis requirements). See generally CALABRESI \& YOO, supra note 75 (discussing the debate over the president's role in policymaking).

129 Exec. Order No. 12,866, § 1(a), 58 Fed. Reg. 51,735 (Sept. 30, 1993). 
OIRA's technical review evaluates the extent to which the draft agency action follows this philosophy. On these topics, OIRA possesses institutional expertise and its review functions as "institutional peer review." 130 It draws on a small, but interdisciplinary, team of economists, scientists, attorneys, engineers, and other professionals with a wide variety of expertise. ${ }^{131}$

Second, OIRA "helps to oversee a genuinely interagency process, involving many specialists throughout the federal government." 132 Sunstein explains that "OIRA's goal is often to identify and convey interagency views and to seek a reasonable consensus, not to press its own positions. While OIRA's own views may well matter, OIRA frequently operates as a conveyer and a convener."133 Although there are many formal and informal relationships between agencies, ${ }^{134}$ OIRA review serves as an opportunity for a comprehensive exchange of views on agency proposals prior to their public release. Given the number of areas of overlapping jurisdiction across agencies, this generally understudied coordination function heads off inconsistencies and otherwise enables the executive branch to communicate its regulatory positions with one voice.

Third, the merits to the President of political review in rulemaking should be clear. ${ }^{135}$ The merits of this to the individual agencies may reasonably vary, based on whether presidential oversight leads to consistent or divergent outcomes with what the agency would choose without such oversight. ${ }^{136}$

Not all agencies are subject to OIRA review. The "independent regulatory agencies" are exempt under EO 12,866. ${ }^{137}$ The exemption cross-references a statutory definition in the Paperwork Reduction Act:

[T] he term "independent regulatory agency" means the Board of Governors of the Federal Reserve System, the Commodity Futures Trading Commission, the Consumer Product Safety Commission, the Federal Communications Commission, the Federal Deposit Insurance Corporation, the Federal Energy Regulatory Commission, the Federal Housing Finance Agency, the Federal Maritime Commission, the Federal Trade Commission, the Interstate Commerce Commission, the Mine Enforcement Safety and Health Review Commission, the National Labor Relations Board, the Nuclear Regulatory Commission, the Occupational Safety and Health Review Commission, the

130 Cary Coglianese, Improving Regulatory Analysis at Independent Agencies, 67 AM. U. L. REV. 733, 750 (2018).

131 See, e.g., Sunstein, supra note 125, at 1856.

132 Id. at 1841 .

133 Id.

134 See generally, e.g., Daniel A. Farber \& Anne Joseph O'Connell, Agencies as Adversaries, 105 CALIF. L. REV. 1375 (2017).

135 See Ryan Bubb \& Patrick Warren, Optimal Agency Bias and Regulatory Review, 43 J. LEGAL STUD. 95, 123-32 (2014) (explaining the value of conflict within the executive branch). See generally Kagan, supra note 3.

136 Kagan, supra note 3, at 2297-98.

137 Exec. Order No. 12,866, § 3(b), 58 Fed. Reg. 51,735 (Sept. 30, 1993). 
Postal Regulatory Commission, the Securities and Exchange Commission, the Bureau of Consumer Financial Protection, the Office of Financial Research, Office of the Comptroller of the Currency, and any other similar agency designated by statute as a Federal independent regulatory agency or commission. ${ }^{138}$

This definition does not set out criteria to qualify as an independent regulatory agency; rather it is mostly a list of specific agencies. The catch-all at the end sweeps in other agencies so-designated by Congress, rather than providing a functional test. ${ }^{139}$ This definition is frequently cross-referenced in presidential executive orders to exempt independent regulatory agencies from various requirements and policies. ${ }^{140}$

But as noted above, upon judicial review, independent regulatory agencies are obliged to justify their regulatory choices in the same manner as other agencies, subject to statutory variation. Independent agencies surely put their regulatory proposals through internal agency vetting, ${ }^{141}$ which often includes economists in various configurations, ${ }^{142}$ and perhaps confer with other agencies. ${ }^{143}$ These important aspects of an agency's regulatory development program cannot be understood to be substitutes for OIRA's interagency review, though, which functions as "institutional peer review." 144 Given the rise of judicial review of agency regulatory analysis, independent agencies, cut off from OIRA review, are at an elevated risk or remand or vacation upon judicial review compared to their OIRA-reviewed counterparts.

While the independent regulatory agencies sometimes provide information about potential effects of their draft rules in their regulatory preambles, it is, as a general matter, scant. ${ }^{145}$ It is not surprising that independent agencies have not

13844 U.S.C. $\$ 3502(5)$ (2012).

139 The Consumer Financial Protection Bureau, for example, was added to this list in its enabling statute. Dodd-Frank Wall Street Reform and Consumer Protection Act, Pub. L. No. 111-203, § 1011(a), 124 Stat. 1376, 1964 (2010).

140 See, e.g., Exec. Order No. 13,771, § 4(c), 82 Fed. Reg. 9339 (Jan. 30, 2017); Exec. Order No. 12,866, § 3(b), 58 Fed. Reg. 51,735 (Sept. 30, 1993).

141 See Jennifer Nou, Intra-Agency Coordination, 129 HARV. L. REV. 421, 468-71 (2015).

142 See generally JERRY ElLIG, AGENCY ECONOMISTS (Sept. 2019), https://www.acus.gov/sites/default/files/documents/Ellig\%20Agency\%20Economists\%20F inal\%20Report\%20September\%202019.pdf [https://perma.cc/U3DX-PATY] (discussing "divisional," "functional," and hybrid methods for organizing agency economists).

143 See Jody Freeman \& Jim Rossi, Agency Coordination in Shared Regulatory Space, 125 HARV. L. REV. 1131, 1155-73 (2012).

144 Coglianese, supra note 130 , at 750 .

145 In an annual report on agency rulemaking, OIRA found that only a portion independent agency rules contained even "some information about costs and benefits." OfFICE OF MGMt. \& Budget, EXEC. OFFICE OF THE PREsIdENT, 2017 REPORT TO CONGRESS

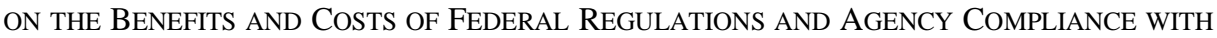
THE UNFUNDED MANDATES REFORM ACT 103-05 (2017), https://www.whitehouse.gov/wp- 
been separately choosing to undertake the kind of analysis that OIRA and courts have in mind. First, they are exempt from the requirements to which other agencies are subject. ${ }^{146}$ Where these agencies are not required to conduct these analyses, they largely do not. ${ }^{147}$ Second, investing in the capacity to conduct this type of analysis, from personnel to data inputs, would involve directing an agency's limited resources away from other activities. ${ }^{148}$ Third, the direct cost of suboptimal regulatory decisions (i.e., those that are not informed by regulatory analysis required by EO 12,866) is generally not borne by the agency, and it might take years for even indirect costs to visit themselves upon the agency. ${ }^{149}$ While there is some evidence that independent regulatory agencies are doing more than generally acknowledged, it is still not a high level of analytical output. ${ }^{150}$ As such, there's a "consensus about independent agencies' analytical deficiencies." 151

Describing the "shortcomings" of analytical work done at independent regulatory agencies, Revesz explained that the Nuclear Regulatory Commission

content/uploads/2019/12/2019-CATS-5885-REV_DOC-2017Cost_BenefitReport11_18_ 2019.docx.pdf [https://perma.cc/GML5-BE4F]. Another OMB report notes:

Independent agencies still have challenges in providing monetized estimates of benefits and costs of regulation .... [F] or the purposes of informing the public and obtaining a full accounting, it would be highly desirable to obtain better information on the benefits and costs of the rules issued by independent regulatory agencies. The absence of such information is a continued obstacle to transparency, and it might also have adverse effects on public policy.

OfFICE OF MGMt. \& Budget, EXeC. OfFICE OF THE PREsident, 2015 REPORT TO CONGRESS

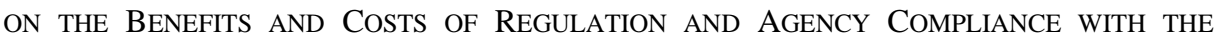
UNFUNDED MANDATES REFORM ACT 27-32 (2015), https://www.whitehouse.gov/sites/white house.gov/files/omb/inforeg/inforeg/2015_cb/2015-cost-benefit-report.pdf [https://perma.cc/ 6CAW-SP9K].

146 CuRtis W. COPElAnd, ECONOMIC ANALYSIS AND INDEPENDENT REgulatory AGENCIES 31, 104 (Apr. 2013), https://www.acus.gov/sites/default/files/documents/Copelan d\%20Final\%20BCA\%20Report\%204-30-13.pdf [https://perma.cc/UNZ7-K2SG] ("Several crosscutting analytical requirements are already potentially applicable to rules issued by independent regulatory agencies. Also, some of the statutes that provide independent regulatory agencies with rulemaking authority contain certain provisions that may require some type of regulatory analysis. Most independent regulatory agencies, however, are not explicitly required to prepare cost-benefit analyses before issuing their rules.... FCC officials indicated that one reason the agency did not prepare cost-benefit analyses more frequently in the past was the absence of a statutory requirement to do so."); Coglianese, supra note 130 , at $741-42$.

147 Coglianese, supra note 130 , at $742-44$.

148 See, e.g., id. at 752.

149 See Ryan Bubb, Comment: The OIRA Model for Institutionalizing CBA of Financial Regulation, 78 L. \& CONTEMP. PROBS. 47, 50 (2015) (explaining that "institutional structures do not produce incentives for financial regulators" to undertake this form of regulatory analysis).

150 Coglianese, supra note 130 , at 743.

${ }^{151}$ Id. 
(NRC) invested tremendous resources into a determination of the value of a statistical life, a valuation that serves as an input into cost-benefit analysis. ${ }^{152}$ The NRC was "isolated from methodological advances" available to other agencies in the executive branch. ${ }^{153}$ The result was a wasteful process to arrive at the same result as the rest of the executive branch. ${ }^{154}$

Some independent regulatory agencies are beginning to try different approaches to meet the increasing demands of judicial review. ${ }^{155}$ After all, no agency wants to expend resources on promulgating a rule just to have it remanded by a court. For example, following Business Roundtable, the SEC implemented several reforms designed to improve its regulatory analysis, including an internal reorganization that strengthened the role of the chief economist, preparation of internal guidance on economic analysis, and the addition of dozens of economists. ${ }^{156}$ These "notable strides" have improved SEC's regulatory analysis. ${ }^{157}$ It has taken years, though, to essentially duplicate OMB's existing guidance on regulatory impact analysis. ${ }^{158}$ And the separate group of SEC economists develops its own approaches to analytical problems, away from OIRA and with no obvious mechanism to coordinate with it. ${ }^{159}$ SEC also lacks access to the formalized interagency review that OIRA coordinates. ${ }^{160}$

In addition, the FCC recently reorganized its economists in an effort to use their skills "optimally" for commission work, including its regulatory actions. ${ }^{161}$ These agencies might have been able to streamline their efforts if they had access to OIRA in a manner that did not imperil their independence. Under the current language of EO 12,866, independent regulatory agencies are excluded from OIRA review. ${ }^{162}$ There is evidence that agencies that undergo OIRA review are better at the kind of regulatory analysis that courts increasingly

152 See Revesz, supra note 4, at 561-63.

153 Id. at 562.

154 See id. at 564-65.

155 See Coglianese, supra note 130, at 745 ("Due to the demands that courts have started to impose on independent regulatory agencies, as well as the generally heightened salience of the issue of regulatory analysis at independent agencies (including the prospect of legislative change), independent regulators appear already to be taking some steps to improve their institutional capacity for producing quality analysis.") (footnote omitted); Lee, supra note 42, at 885 (discussing additional scrutiny for independent agencies after Business Roundtable).

156 Ellig, supra note 65, at 5-6.

157 Coglianese, supra note 130 , at 745.

158 See Revesz, supra note 4, at 565-70.

159 See Coglianese, supra note 130 , at 745.

160 See id. at 746.

161 Ajit Pai, Chairman, FCC, The Importance of Economic Analysis at the FCC 2, 5 (Apr. 5, 2017), https://docs.fcc.gov/public/attachments/DOC-344248A1.pdf (on file with the Ohio State Law Journal).

162 See Exec. Order No. 12,866, § 3(b), 58 Fed. Reg. 51,735 (Sept. 30, 1993). 
scrutinize. ${ }^{163}$ This article does not attempt to suggest that agencies subject to OIRA review produce perfect analyses, but that the OIRA review process has a salutary effect on agency analysis and therefore regulatory decision-making. ${ }^{164}$

As will be explained below, it is likely that the decision to wall off independent regulatory agencies from OIRA review was done out of political, rather than legal, concern. It also, though, walled these agencies off from both OIRA's technical expertise and the formal interagency network of practitioners working on similar issues at their respective agencies. Now that the stakes for regulatory analysis are higher, the time is right to address the unintended consequences of the independent regulatory agencies' exemption from OIRA review.

\section{FAILED EFForts to CHANGE THE StATUS QUO}

Pressure from judicial review creates a new incentive to revisit a decision from 1981 that cemented the relationship between OIRA and the independent regulatory agencies. Over the years, scholars and practitioners have called for OIRA's review of independent regulatory agencies, but the details of how that review would function in practice are not often discussed. Rather, the emphasis has largely been confined to describing perceived shortcomings of the status quo. Congress could certainly resolve the issues by legislating, but it has not successfully done so. This section considers the 1981 decision and subsequent calls for change.

163 See Jerry Ellig \& Hester Peirce, SEC Regulatory Analysis: “A Long Way to Go and a Short Time to Get There”, 8 BROOK. J. CORP. Fin. \& COM. L. 361, 381 (2014); Arthur Fraas \& Randall Lutter, On the Economic Analysis of Regulations at Independent Regulatory Commissions, 63 ADMIN. L. REV. 213, 236 (2011) ("[T]his review suggests that the economic analyses prepared by independent regulatory commissions do not measure up to those of the executive branch agencies."); Hester Peirce, Economic Analysis by Federal Financial Regulators, 9 J.L., ECON. \& POL'Y 569, 585 (2013); Jerry Ellig \& Rosemarie Fike, Regulatory Process, Regulatory Reform, and the Quality of Regulatory Impact Analysis 4445 (Mercatus Ctr., George Mason Univ., Working Paper No. 13-13, 2013), https://www.mer catus.org/system/files/Ellig_RegulatoryProcess_v1.pdf [https://perma.cc/5UUZ-CZPP]. Revesz also cites recent empirical work to demonstrate that the independent agencies excluded from OIRA review are "less successful" at cost-benefit analysis of draft regulations. Revesz, supra note 4, at 560 (citing Howell E. Jackson \& Paul Rothstein, The Analysis of Benefits in Consumer Protection Regulations (Dec. 2015) (unpublished manuscript), https://www.law.ox.ac.uk/sites/files/oxlaw/jackson_and_roths tein_article_december_2015.pdf [https://perma.cc/8TQB-S9VF]). The work can now be found at Howell E. Jackson \& Paul Rothstein, The Analysis of Benefits in Consumer Protection Regulations, 9 HARV. BuS. L. REV. 197 (2019).

164 See, e.g., Kagan, supra note 3, at 2340 ("The practice of OMB review over the last twenty years in fact has enhanced ... the capacity of the administrative system ...."); see also Robert W. Hahn \& Patrick M. Dudley, How Well Does the U.S. Government Do BenefitCost Analysis?, 1 REV. ENVTL. ECON. \& POL'Y 192, 195-96 (2007) (examining the quality of agency regulatory analysis). 


\section{A. History of the Exemption from OIRA Review}

The history of independent regulatory agencies' exemption from OIRA review goes back to EO 12,291, which established regulatory review in the Reagan administration. ${ }^{165}$ Two versions of this EO were drafted: one included independent regulatory agencies, and one did not. ${ }^{166}$ Both were sent to the Office of Legal Counsel (OLC) at the Department of Justice, which opined that both drafts were lawful. ${ }^{167}$ Demonstrating how close President Reagan came to applying regulatory oversight to the independent regulatory agencies, OLC's legal opinions were offered just days before EO 12,291 was signed. ${ }^{168}$

There was a bevy of political and legal questions at the time. ${ }^{169} \mathrm{C}$. Boyden Gray testified before Congress on the subject:

The EO, by its terms, does not cover the independent agencies. This is not so much that we thought we lacked certain legal authority to do certain things, since I think we could have extended the EO and might still in the future. We chose not to do it really because of policy reasons ... [W]e had our plate more than full with the Executive Branch Agencies which do impose[,] by far[,] the greatest percentage of capital cost[] burdens that we think were issued during the campaign. We just didn't want to spread ourselves too thin. If we can get the main regulatory problems under control, we'll actually focus at that point more on the independents, but we'll wait and see how much progress we make with the Executive Branch. ${ }^{170}$

Katzen described the decision not to include the independent agencies in EO 12,291, and then again in EO 12,866 as "essentially for political reasonsnamely, deference to Congress, which traditionally views the [independent regulatory commissions] as 'its' agencies, not the President's." 171 Neither,

165 Exec. Order No. 12,291, § 1(d), 3 C.F.R. § 127 (Feb. 17, 1981).

166 See Memorandum from Larry L. Simms, Acting Assistant Attorney Gen., Office of Legal Counsel, Dep't of Justice, to David Stockman, Dir., Office of Mgmt. and Budget 7 (Feb. 12, 1981) (describing analysis of a version of the EO that included independent agencies under its purview), reprinted in Role of $O M B$ in Regulation: Hearing Before the Subcomm. on Oversight and Investigations of the H. Comm. on Energy and Commerce, 97th Cong. 152, 158 (1981) [hereinafter Simms Memorandum].

167 Id. at 163 .

$168 I d$. at 152.

169 Although they did not appear to factor into the analysis, there would also have been practical considerations, such as those described infra at text accompanying notes 214-15.

${ }^{170}$ Hall of Flags Regulation Reform: Briefing Before the Subcomm. on Oversight \& Investigations of the H. Comm. on Energy and Commerce, 97th Cong. 24 (1980) (statement of C. Boyden Gray, Counsel to the Vice President), reprinted in Role of OMB in Regulation: Hearing Before the Subcomm. on Oversight and Investigations of the H. Comm. on Energy and Commerce, 97th Cong. 87, 94 (1981).

${ }^{171}$ Sally Katzen, OIRA at Thirty: Reflections and Recommendations, 63 ADMIN. L. REV. 103, 109 (2011). 
notably, signaled that they were legally unable to extend the executive orders to independent agencies.

But there were legal questions, generally centered on the uncertainty of limitations on the President's authority to supervise the independent regulatory agencies. ${ }^{172}$ The February 12, 1981 OLC memorandum responds to the draft EO that included the independent regulatory agencies. ${ }^{173}$ It deals, at length, with the legal and political considerations associated with this proposed action. ${ }^{174}$ The memo considers whether the President can impose both procedural requirements, such as the preparation of regulatory impact analyses, as well as his or her substantive policy views upon the heads of independent regulatory agencies. ${ }^{175}$ The memo concludes that efforts to do either are in tension with dicta from Humphrey's Executor v. U.S. ${ }^{176}$ “endorsing a perceived congressional purpose to insulate [independent agencies] almost entirely from Presidential supervision." 177 Taking this dicta "at face value, the President's constitutional power to supervise the independent agencies is limited to his power of appointment, and none of the proposed Order's requirements may legally be applied to the independent agencies." 178

The memo then sets out several reasons why the Court "would ... retreat from these dicta." 179 The first is that Humphrey's Executor was a case regarding agency adjudication, rather than rulemaking. ${ }^{180}$ Second, whether an agency is independent or not, it "engage[s] in rulemaking in a fundamentally indistinguishable fashion." 181 Third, the Court in Humphrey's Executor was relying on "an outmoded view about the "apolitical' nature of regulation," rather than modern understanding that political influence comes to bear on many aspects of the rulemaking process. ${ }^{182}$ Fourth, it noted the various statutory powers that Congress has granted the president over independent agencies, such as the budgetary and legislative review. ${ }^{183}$

172 See, e.g., Lessig \& Sunstein, supra note 74, at 112 (noting that executive authority over independent agencies was unclear); Peter M. Shane, Independent Policymaking and Presidential Power: A Constitutional Analysis, 57 GEO. WASH. L. REV. 596, 611 (1989) (finding narrow and broad textual support for agency independence); Strauss, supra note 68, at 596.

173 Simms Memorandum, supra note 166, at 152.

174 Id. at $153-64$.

$175 \mathrm{Id}$. at $154-58$.

176295 U.S. 602, 624 (1935).

177 Simms Memorandum, supra note 166, at 158-64.

178 Id. at 160.

$179 \mathrm{Id}$.

${ }^{180} \mathrm{Id}$. at 160 .

181 Id. at $160-61$.

182 Id. at 161. See generally Andreas Eriksen, Political Values in Independent Agencies, REG. \& GOVERNANCE (forthcoming) (on file with the Ohio State Law Journal) (describing the inevitability of political judgments being made by independent agencies).

183 Simms Memorandum, supra note 166, at 161-62. 
Ultimately, OLC concluded that the president may require all agencies to prepare a regulatory impact analysis ${ }^{184}$ under his or her Article II authorities to "take Care that the Laws be faithfully executed"185 and to "require the Opinion, in writing, of the principal Officer in each of the executive Departments, upon any Subject relating to the Duties of their respective Offices."186 It emphasized caution on any provisions that would result in "Presidential supervision on matters of substantive policy." 187 The memo distinguished this from provisions that "consist[] of a coordinating role with only an indirect effect on substantive policymaking." 188 OLC's opinion was that the draft provisions navigated this tension adequately, and that the extension to independent regulatory agencies would be lawful. ${ }^{189}$

The second OLC memo, dated February 13, 1981, does not discuss the draft executive order's application to independent regulatory agencies, reflecting the executive order that was signed by President Reagan the following week on February 17, 1981. 190 That order, EO 12,291, locked in the policy that excludes independent regulatory agencies from OIRA review to this day. ${ }^{191}$

The unintended consequence of that choice is that there is one set of regulations that has long been subject to the analytical requirements of EO 12,866 , and another that has not. While cellphones, children's products, clothing labels, and nuclear power plants are exempt, ${ }^{192}$ pharmaceuticals, passenger cars, endangered species, and occupational safety are covered. ${ }^{193}$ Depending on your

${ }^{184}$ Id. at $153-56$.

185 U.S. CONST. art. II, $\S 3$.

186 Id. § 2.

187 Simms Memorandum, supra note 166, at 161.

188 Id. at 163.

189 Id. The American Bar Association and the Administrative Conference of the United States have agreed that, as a legal matter, the President may direct the independent regulatory agencies to conduct regulatory analysis. Presidential Review of Agency Rulemaking (Recommendation 88-9), 54 Fed. Reg. 5207, 5208-09 (Feb. 2, 1989); Letter from Thomas M. Susman, Dir., Am. Bar Ass'n Governmental Affairs Office, to Senator Thomas R. Carper and Senator Tom A. Coburn, at 2 (Sept. 16, 2013) (on file with the Ohio State Law Journal).

190 Memorandum from Larry L. Simms, Acting Assistant Attorney Gen., Office of Legal Counsel, Dep't of Justice, to David Stockman, Dir., Office of Mgmt. and Budget (Feb. 13, 1981), reprinted in 5 OPINIONS OF THE OFFICE OF LEGAL COUNSEL OF THE UNITED STATES DEPARTMENT OF JuSTICE 59, 61 (Margaret Colgate Love ed., 1981).

191 Exec. Order No. 12,291, § 1(d), 3 C.F.R. 128 (Feb. 17, 1981).

192 The listed items are regulated by the Federal Communications Commission, the Consumer Products Safety Commission, the Federal Trade Commission, and the Nuclear Regulatory Commission, respectively. See Other Federal Agencies, PERFormancE.GOV, https://www.performance.gov/other-federal-agencies/ [https://perma.cc/QPN8-JU6F].

193 These items are regulated by the Departments of Health \& Human Services, Transportation, Interior, and Labor, respectively. See Department of Health and Human Services, PERFORMANCE.GOV, https://www.performance.gov/health-and-human-services/ [https://perma.cc/87G9-7XB4]; Department of the Interior, PERFORMANCE.GOV, https://www.performance.gov/interior/ [https://perma.cc/HP7Q-8PZ9]; Department of Labor, PERFORMANCE.GOV, https://www.performance.gov/labor/ [https://perma.cc/E7VJ- 
view of the role of economic analysis in regulation, this might be frustrating or a relief. Either way, it is incoherent, because - even if one supports the idea of political insulation for decision-making purposes - there is no meaningful way to explain why these different regulatory areas should be analyzed differently.

In light of deeper understanding of the nature of agency independence, it is clear that the definition of "independent regulatory agency" draws a bright line at the expense of coherence. As Cary Coglianese has noted, the agencies listed in the Paperwork Reduction Act definition "do not uniformly share the same structural features. Most have agency heads protected by for-cause removal limitations, but some do not ... [and the] list does not include some agencies headed by administrators who do enjoy for-cause removal protection ...."194 When EO 12,291, and EO 12,866 after it, referred to the statutory definition of "independent regulatory agency," it opted for a categorical, as opposed to a functional, test for exclusion from regulatory review.

While the bright line has offered certainty about whether OIRA would review these agencies' regulatory actions, the trade-off is that regulatory review has been cut off from these agencies whether their level of independence called for it, or not. The result is that the current approach to excluding independent regulatory agencies from OIRA review - that is, the statutory list ${ }^{195}$ — cannot be assured to offer agencies a level of independence commensurate with that which Congress gave them or which has emerged over time. Like a dock that can float up and down on the tide, agency independence is not fixed in one position. The policy domain has not yet absorbed these scholarly insights. Instead, OIRA review of independent regulatory agencies remains fixed to a stale understanding of agency independence.

\section{B. Calls for Change}

Many have called to revisit this exemption from OIRA review. Proposals for action by Congress, the courts, or the President have not led to resolution. Instead, there is a need for a new idea, one that takes advantage of judicial attention towards regulatory analysis and leverages what Kagan has called the "dynamic charge" of the executive. ${ }^{196}$

Among those who have called for independent regulatory agencies to be subject to OIRA review is a group of scholars and practitioners who have spent time working in or with OIRA. ${ }^{197}$ But there is also support from scholars who are not OIRA insiders. For example, Datla and Revesz argued:

EUD9]; Department of Transportation, PERFORMANCE.GOV, https://www.performance.gov/ transportation/ [https://perma.cc/PQY7-EG27].

194 Coglianese, supra note 130 , at 739.

195 Exec. Order No. 12,291, § 1(d), 3 C.F.R. 128 (Feb. 17, 1981).

196 Kagan, supra note 3, at 2339, 2384.

197 Robert W. Hahn \& Cass R. Sunstein, A New Executive Order for Improving Federal Regulation? Deeper and Wider Cost-Benefit Analysis, 150 U. PA. L. REV. 1489, 1494 (2002) ("[T]he commitment to cost-benefit analysis has been far too narrow; it should be widened 
As a policy matter, it also is unsound for the President to keep exempting independent agencies from the regulatory review program. These agencies have issued and will continue to issue regulations that impose significant costs on the economy, just as executive branch agencies do. Not only do so-called independent agencies impose great costs on regulated entities, they often do so with little analysis of those costs or alternatives during the drafting process. If regulatory review is a good practice for agencies traditionally considered to be part of the executive branch, as Presidents have recognized for more than three decades, it is also a good practice for agencies that have traditionally been regarded as independent. ${ }^{198}$

Coglianese has also pointed out the arbitrariness of the exemption: "[T]he regulations that independent agencies adopt show no meaningful disparity in substantive significance that would justify continuing to exempt them entirely from analytic requirements. Independent agencies' regulations are in fact highly consequential to the economy and to overall societal well-being."199

Proposals for Congress, the courts, or the President to address this issue have not been successful. Former OIRA Administrator Sally Katzen proposed that Congress enact a version of OIRA review that would permit independent regulatory agencies to overrule OIRA in the event of a dispute. ${ }^{200}$ Cary Coglianese has described a similar approach.201 Senator Rob Portman introduced a bill in 2012 requiring independent regulatory agencies to prepare and submit regulatory analyses to OIRA. ${ }^{202}$ It did not require those agencies to incorporate OIRA's suggestions, but gave permission to allow OIRA to submit its assessment of the rule to the regulatory record and require the agency to explain in its final rule if it did not address OIRA's concerns. A coalition of five

through efforts to incorporate independent regulatory commissions within its reach."); Katzen, supra note 171, at 109 ("I now believe that requirements for economic analysis and centralized review should be extended to the Independent Regulatory Commissions. . . . The problems that plague our nation do not fit neatly into one agency. Consider the recent financial meltdown, which implicated multiple agencies, including both executive branch agencies (e.g., Treasury) and IRCs (e.g., Federal Reserve)."); James C. Miller III, The Early Days of Reagan Regulatory Relief and Suggestions for OIRA's Future, 63 ADMIN. L. REV. 93, 100 (2011); Susan E. Dudley \& Sally Katzen, Commissions Are Mulvaney's Error of Omission, WALl ST. J. (Aug. 5, 2018), https://www.wsj.com/articles/commissions-aremulvaneys-error-of-omission-1533496398 [https://perma.cc/S3TF-YYFC].

198 Datla \& Revesz, supra note 75, at 839-40 (footnote omitted).

199 Coglianese, supra note 130, at 767 (footnote omitted).

200 Sally Katzen, Expand Centralized Regulatory Review to Independent Agencies, REG. REV. 3 (Aug. 9, 2011), https://www.law.upenn.edu/blogs/regblog/2011/08/expandcentralized-regulatory-review-to-independent-agencies.html [https://perma.cc/BA6A-2SZ9].

201 Coglianese, supra note 130, at 748. He also suggested that Congress could amend the Unfunded Mandates Reform Act to accomplish a similar goal. Id. at 749-53.

202 S. 3468, 112th Cong. § 3(c)(1)(A)-(B) (2012). 
independent regulatory agencies, all of whom enjoy legislative bypass, communicated its concern about the bill. ${ }^{203}$ Its complaint was that:

This [bill] would give any President unprecedented authority to influence the policy and rulemaking functions of independent regulatory agencies and would constitute a fundamental change in the role of independent regulatory agencies. Beyond injecting an Administration's influence directly into our rulemaking, the bill would also interfere with our ability to promulgate rule critical to our missions in a timely manner and would likely result in unnecessary and unwarranted litigation in connection with our rules. ${ }^{204}$

The bill was not enacted in the 112th Congress, but it has been reintroduced in more recent years. ${ }^{205}$

Turning to the courts, Sharkey has proposed that courts give less deference to rules that do not undergo OIRA review. ${ }^{206}$ This would provide indirect incentives to the independent regulatory agencies to seek out OIRA review. So far, judges have not embraced this proposal as part of their heightened judicial review of agency regulatory analysis. ${ }^{207}$ This is perhaps because of Vermont Yankee Nuclear Power Corp. v. Natural Resources Defense Council, 208 under which courts are restricted from imposing new procedural requirements on agencies. ${ }^{209}$ Hahn and Sunstein suggested that for-cause removal could be satisfied by an agency head's defiance of a presidential order to conduct costbenefit analysis. ${ }^{210}$

Calls for executive action to pull the independent regulatory agencies under OIRA review are either short on specifics ${ }^{211}$ or arguably unworkable. The most specific proposal for executive action included a draft of an executive order to replace EO 12,866. ${ }^{212}$ It provides a definition of "agencies" that simply includes

203 Letter from Ben S. Bernanke, Chairman, Bd. of Governors of the Fed. Reserve Sys., Mary L. Schapiro, Chairman, SEC, Thomas J. Curry, Comptroller of the Currency, Martin J. Gruenberg, Acting Chairman, Fed. Deposit Ins. Corp., Richard Cordray, Dir., Consumer Fin. Prot. Bureau, \& Debbie Matz, Chairman, Nat'l Credit Union Admin., to Senator Joseph Lieberman \& Senator Susan Collins, at 1 (Oct. 26, 2012), https://buckleyfirm.com/uploads/ 104/doc/10-26-12\%20Agency\%20Letter\%20to\%20Lieberman\%20re\%20S\%203468.pdf [https://perma.cc/ZSF3-Z54J].

204 Id.

205 S. 3208, 116th Cong. (2020); S. 1607, 114th Cong. (2015).

206 Sharkey, supra note 4, at 1592-93. An intriguing possibility for empirical work is to explore whether courts are effectively doing this without expressly mentioning it in their decisions.

207 See, e.g., id. at 1615.

208 Vt. Yankee Nuclear Power Corp. v. Nat. Res. Def. Council, 435 U.S. 519 (1978).

209 Id. at 524.

210 See Hahn \& Sunstein, supra note 197, at 1535-37.

211 E.g., C. Boyden Gray, The President's Constitutional Power to Order Cost-Benefit Analysis and Centralized Review of Independent Agency Rulemaking 29 (unpublished manuscript) (on file with the Ohio State Law Journal).

212 Hahn \& Sunstein, supra note 197, at 1542. 
the "independent regulatory agencies" with a cross-reference to the Paperwork Reduction Act definition. ${ }^{213}$ There are many problems with such an approach.

First, a solution that simply sweeps the independent regulatory agencies under OIRA's purview fails to account for the insulating features given to it by Congress, which would make implementation unnecessarily chaotic. Without plans for dispute resolution, the ultimate constitutional question is likely to be called quickly: can the President fire an independent regulatory agency head as part of a regulatory dispute? As explained above, independent regulatory agencies have different levels of manifest independence, and treating them the same may backfire.

Second, practical problems abound. The most obvious is that independent regulatory agencies are structured quite differently from other agencies, often with multimember bodies in charge of decision-making. As Coglianese notes:

A multimember body simply could not engage in the kind of back-and-forth interactions contemplated by Executive Order 12,866. The practice of regulatory review under the Order routinely involves a working interchange and dialogue between an agency head (or designee) and the OIRA Administrator (or designee), a process which as a practical matter would not work well with multimember bodies. If the entire multimember body were taken to constitute the agency "head," then the review process would become extremely cumbersome. Merely determining an agency's position on OIRA's feedback on the agency's regulatory impact analysis would presumably necessitate a meeting with all commission members in accordance with various Government in the Sunshine Act requirements-including open meetings. ${ }^{214}$

He also notes: "It is highly doubtful that White House officials would want to conduct their meetings with multimember commissions in the open." 215

Third, OIRA would also face serious resource limitations if all of the independent regulatory agencies were suddenly subjected to review. OIRA has roughly fifty staff, only a subset of whom review draft agency regulations. ${ }^{216}$ OIRA would likely need to secure additional resources and hire additional staff, both of which take time. ${ }^{217}$ On the agency side, suddenly being subject to OIRA review would trigger a need for a rapid ramp-up in capabilities that might prove extremely challenging. ${ }^{218}$

213 Id. at 1546.

214 Coglianese, supra note 130, at 747-48 (footnotes omitted).

215 Id. at 748 n.66.

216 Office of Management and Budget, Information and Regulatory Affairs, WHITE HousE, https://www.whitehouse.gov/omb/information-regulatory-affairs/ [https://perma.cc/ G3BU-NGN2].

217 Coglianese, supra note 130, at 749.

218 See id. at 751 ("Pursuing a middle ground, rather than going to the extreme of involving OIRA in the work of independent agencies, would seem especially prudent in light of limitations in current assessments of the adequacy of regulatory analysis at independent agencies."). 
Prior proposals for executive action, therefore, have not offered a realistic plan for the executive that could proceed absent legislative action. While Congress could certainly resolve this issue at any time, there is a need for a new idea that leverages what Kagan has called the "dynamic charge" of the executive to solve this problem. ${ }^{219}$

Writing about the benefits of centralized regulatory review, Kagan explains that improved regulatory decision-making is not merely a function of a process involving technocratic tools. ${ }^{220}$ That, she says, "does not fully explain a decision to lodge ... these functions within the hands of the President." 221 Instead, she considers "the common bureaucratic pathologies of rigidity and torpor," finding that "to achieve even technocratic goals, some real push from the political system is needed." 222 This "dynamism" is not something to be tolerated within a political system, but is indeed a critical aspect of it. ${ }^{223}$

Applying this concept to the issue of independent regulatory agencies, the question remains how a president can invoke this dynamic charge to spur forward movement and not merely a backlash from the independent regulatory agencies themselves, or from Congress.

With heightened judicial scrutiny of regulatory analysis, the independent regulatory agencies are uniquely disadvantaged compared to others when it comes to regulatory analysis. Despite calls for change, neither Congress, the courts, nor the President have altered the status quo. This state of affairs lags woefully behind the scholarship on agency independence, which has offered critical new insights.

\section{BESPOKE REGULATORY REVIEW}

To summarize, the rise of judicial review of agency regulatory analysis carries unique risks for independent regulatory agencies. The modern understanding of independent agencies, that they are both fluid and dynamic, calls into question the rigid, fixed list of independent regulatory agencies exempt from OIRA review. Calls to subject these agencies to OIRA review drift in the doldrums, waiting perhaps for a calibrated gust from the executive. The hydraulic movements of the courts, the legislature, and the executive, combined with insights from the academy, create the conditions for a new possibility: bespoke regulatory review. That is, a series of bilateral negotiations that result in memoranda of agreement between OIRA and the independent regulatory agencies.

These agreements would provide for a form of OIRA review that is tailored to the specifics of an independent regulatory agency. There is precedent for this kind of negotiation and agreement, and perhaps it is best to view OIRA review

219 Kagan, supra note 3, at 2384.

220 Id. at $2340-41$.

221 Id. at 2340.

222 Id. at 2341.

223 Id. at $2340-41$. 
as long having been the byproduct of many different forms of negotiation. Shortly after EO 12,866 was signed, then-Administrator Sally Katzen issued a memorandum that included a list of negotiated exemptions - both for certain agencies and for certain regulatory actions-from OIRA review. ${ }^{224}$ On a transactional level, the length of OIRA review can vary. ${ }^{225}$ And the contents of rules themselves might sometimes be the product of informal agreements between OIRA and agencies designed to avoid "tactical splitting" that would otherwise allow the rules to evade OIRA review. ${ }^{226}$

Most recently, OIRA's willingness to negotiate terms of its review with the Internal Revenue Service (IRS) ${ }^{227}$ suggests that there may be more flexibility to OIRA review than is well understood at present. This development opens up a lane to resolve this issue and connect independent regulatory agencies to OIRA's technical expertise without unduly disrupting their independence. This section offers some examples for the content of the agreements based on past precedent and the unique needs of independent regulatory agencies. It closes with a discussion of the policy and other considerations associated with the proposal.

\section{A. Existing OIRA Review Agreements}

In April 2018, the U.S. Department of Treasury and the Office of Management and Budget (OMB) signed a memorandum of agreement $(\mathrm{MOA})^{228}$ adjusting the scope of OIRA review. Before the IRS MOA, the prospect of OIRA review appeared to be an all-or-nothing proposition: either submit to the full set of OIRA review mechanisms or resist them all. The stakes of working with OIRA appeared very high, especially against a backdrop of rising executive power. The leadership of an independent regulatory agency, even if intrigued by the potential of working with OIRA, may have reasonably stayed away.

However, increased judicial scrutiny of agency regulatory analyses augments previously low incentives for independent regulatory agencies to produce better analysis. Combined with the flexibility revealed by the IRS MOA, enough may have changed to make progress possible.

224 Memorandum from Sally Katzen, Adm'r, OIRA, to Heads of Exec. Dep'ts and Agencies, and Indep. Regulatory Agencies 11, 13-16 (Oct. 12, 1993), https://www.white house.gov/sites/whitehouse.gov/files/omb/assets/inforeg/eo12866_implementation_guidan ce.pdf [https://perma.cc/Q7YY-BHFL].

225 See generally, e.g., Alexander Bolton, Rachel Augustine Potter, \& Sharece Thrower, Organizational Capacity, Regulatory Review, and the Limits of Political Control, 32 J.L. ECON. \& ORG. 242 (2016) (discussing, analyzing, and hypothesizing upon the reasons for varying OIRA review times).

226 Jennifer Nou \& Edward H. Stiglitz, Regulatory Bundling, 128 YALE L.J. 1174, 1208 (2019).

227 Bridget C.E. Dooling, OIRA's Expanded Review of Tax Regulations and Its Surprising Implications, 3 BUS. ENTREPRENEURSHIP \& TAX L. REV. 224, 235 (2019).

228 MEMORANDUM OF AGREEMENT, supra note 1, at 3. 
There are two formal agreements in place between OIRA and agencies. ${ }^{229}$ The first agreement sets out terms for OIRA to offer technical assistance for the draft regulations of an independent regulatory agency, the Commodity Futures Trading Commission; it holds OIRA at arm's length and relies on the independent regulatory agency to begin consultations at its discretion. ${ }^{230}$ The second agreement renegotiates an older compromise between OIRA and a nonindependent agency, the IRS, which was largely excluded from OIRA review in the past. ${ }^{231}$ This second agreement is much closer to regular OIRA review than the first, with the agency submitting its rules to OIRA as a matter of routine, rather than at the agency's initiative. The agreements are therefore quite different from each other, but together they suggest that this method of engagement - negotiation, resulting in an agreement — can be fruitful for both parties.

\section{Commodity Futures Trading Commission MOU}

In 2012, OIRA Administrator Cass Sunstein signed a memorandum of understanding (MOU) ${ }^{232}$ with the Commodity Futures Trading Commission (CFTC), ${ }^{233}$ which is an independent regulatory agency. This MOU was signed two years after the Dodd-Frank Wall Street Reform and Consumer Protection Act required the CFTC to consider costs and benefits in its rulemakings and orders. $^{234}$ CFTC faced litigation challenging its Dodd-Frank Act implementation rulemakings on, inter alia, the quality of its regulatory impact

229 There may be other, less formal arrangements between OIRA and certain agencies to permit for informal consultation. OIRA works with independent regulatory agencies to implement the Paperwork Reduction Act, Congressional Review Act, as well as to issue the Semi-Annual Unified Regulatory Agenda, and therefore the staff have informal relationships with each other even though OIRA does not review their rules under EO 12866. The Federalist Society, Opening Address: Hon. Neomi Rao [EBR6], YouTuBE (Apr. 25, 2018), https://www.youtube.com/watch?v=IcteDU2hgGw [https://perma.cc/N4YE-XDKN] [hereinafter Opening Address] (discussing independent agencies at 17:24).

230 See Jamila Trindle, CFTC Taps Help for Cost Analysis on New Rules, WALL ST. J. (May 10, 2012), https://www.wsj.com/articles/SB100014240527023040703045773961926 53277890 [https://perma.cc/CL6W-9VC5].

231 Dooling, supra note 227, at 229.

232 Agencies often use memoranda of understanding (MOUs) or memoranda of agreement (MOAs) to memorialize the results of an interagency negotiation. See Farber \& O’Connell, supra note 134, at 1409-10.

233 Office of Mgmt. \& Budget \& U.S. Commodity Futures Trading Comm’n, MEMORANDUM OF UNDERSTANDING (May 9, 2012), https://www.whitehouse.gov/sites/white house.gov/files/omb/inforeg/inforeg/regpol/oira_cftc_mou_2012.pdf [https://perma.cc/BA6 V-P9KC] [hereinafter MEMORANDUM OF UnDERSTANDING].

234 Dodd-Frank Wall Street Reform and Consumer Protection Act, Pub. L. No. 111203, § 115, 124 Stat. 1376, 1403 (2010). 
analysis. ${ }^{235}$ The MOU, signed in the wake of this litigation, sets out a process for OIRA staff to provide technical assistance to CFTC during the implementation of the Dodd-Frank Act, with an emphasis on advice to inform CFTC's consideration of costs and benefits in proposed and final rulemaking proceedings. ${ }^{236}$ When the MOU was announced, Commissioner Scott O'Malia "praised the greater cooperation with OIRA, which he said holds the gold standard for cost-benefit analysis." 237

The MOU states that it "is set forth for the purpose of permitting [OIRA] to provide technical assistance to the [CFTC]." ${ }^{238}$ It provides that OIRA may provide technical assistance but that in accepting such assistance CFTC is not subjecting itself to OIRA review under EO $12,866 .{ }^{239}$ As such, the CFTC MOU keeps OIRA at arm's length, with CFTC contacting OIRA for assistance only at its discretion. ${ }^{240}$ This feature indicates that CFTC perceived the full version of OIRA review to be incompatible with its independence. The MOU also provides that sharing information under the arrangement does not disrupt any lawful privilege and confidentiality and that the MOU shall continue until both parties revise or modify it. ${ }^{241}$

No other independent regulatory agency is known to have executed agreements with OIRA to fulfill a similar technical assistance function, despite some evidence that the CFTC MOU has been at least modestly successful. ${ }^{242}$ There could be several reasons why this OIRA technical assistance model has not spread. First, other agencies simply might not know about it as an option. Although it did get some press initially, ${ }^{243}$ it has not been a particularly newsworthy arrangement since it was established. Second, OIRA might not be actively trying to encourage other agencies to sign on to a similar arrangement,

235 Revesz, supra note 4, at 571; Garrett F. Bishop \& Michael A. Coffee, Note, A Tale of Two Commissions: A Compendium of the Cost-Benefit Analysis Requirements Faced by the SEC \& CFTC, 32 REV. BANKING \& FIN. L. 565, 605-06 (2013); Trindle, supra note 230.

236 MEMORANDUM OF UNDERSTANDING, supra note 233.

237 Trindle, supra note 230. Commissioner Bart Chilton, however, dismissed the MOU as "in no way a commentary on any past or current litigation," and said MOUs were "a dime a dozen." Id. Although CFTC has many MOUs listed on its website, and seems to engage in the practice regularly, this was the first time OIRA negotiated the terms of its review or technical assistance with an independent regulatory agency. Revesz, supra note 4, at 573.

238 MEMORANDUM OF UNDERSTANDING, supra note 233.

239 See id. Commissioner Chilton commented when the MOU was announced that it would not affect CFTC's independence. See Trindle, supra note 230.

240 See Exec. Order No. 12,866, 58 Fed. Reg. 51,735 (Sept. 30, 1993); MEMORANDUM OF UNDERSTANDING, supra note 232.

241 MEMORANDUM OF UNDERSTANDING, supra note 233.

242 See Comm. on Capital Mkts. Regulation, A Balanced Approach to CostBENEFIT ANALYSIS REFORM 8 (Oct. 2013), https://www.capmktsreg.org/wp-content/uploads /2018/10/A-Balanced-Approach-to-Cost-Benefit-Analysis-Reform.pdf [https://perma.cc/ 3EWE-PSNV] ("The incidence of quantitative analysis performed by the CFTC has increased since OIRA began providing technical support, and the length, detail, and quality of the analysis have improved to a degree.").

243 E.g., Trindle, supra note 230. 
either because the arrangement has not been viewed as a good investment of resources, or simply due to other priorities facing the small office. ${ }^{244}$ Third, OIRA technical assistance might not have been sufficiently appealing to independent regulatory agencies to justify the additional time and resources required to build new working relationships with OIRA. Fourth, an agency might perceive that any interaction with OIRA related to draft regulations places its independence at risk. ${ }^{245}$ Fifth, the agencies might be disinterested in receiving the advice, choosing to proceed on their own. ${ }^{246}$ Sixth, and perhaps least intuitively, an agency's willingness to receive technical assistance might not be a strong enough commitment to allow it to follow through on the kinds of analytical and organizational changes that could follow from OIRA's analytical review.

On this last point, Sharkey has explained that both judicial review and OIRA review are "information forcing," meaning that they result in "the development of more robust agency records subject to oversight, all in the pursuit of better (i.e., more rational and coherent) agency decision-making." 247 This activity comes at a resource cost to agencies. They might need to hire economists and other professionals to prepare the kind of information that OIRA review seeks. $^{248}$

In addition, OIRA review under EO 12,866 asks questions that agencies are sometimes reluctant to answer. For example, EO 12,866 directs agencies to explain the problem it aims to address with its revised rule. ${ }^{249}$ Although this sounds like a modest request, agencies sometimes argue that they are under a statutory requirement to act, rather than explaining the problem to which they are responding. ${ }^{250}$ EO 12,866 also directs agencies to assess alternative approaches to addressing the problem that has been identified. ${ }^{251}$ But agencies sometimes experience pressure to suggest that the proposed regulatory approach is the only option, rather than acknowledging that there might be other alternatives. ${ }^{252}$

A technical assistance model, which allows the agency to take or leave advice on any particular rule, without a larger commitment to the endeavor, therefore may lead to anemic uptake of OIRA's advice provided under such a

244 See, e.g., Exec. Order No. 13,771, § 1, 82 Fed. Reg. 9339 (Jan. 30, 2017) (creating the regulatory two-for-one and regulatory budget initiatives).

245 As noted above, OIRA interacts with these agencies already in non-regulatoryreview capacities (e.g., statistical, information collection review under the PRA, privacy). See Memorandum of Understanding, supra note 233.

246 See supra notes 154-61 and accompanying text.

247 Sharkey, supra note 4, at 1604.

248 Id. at 1622.

249 Exec. Order No. 12,866, § 1(b)(1), 58 Fed. Reg. 51,735 (Sept. 30, 1993).

250 See Jerry Ellig \& Michael Horney, Statutory Delegation, Agency Authority, and the Asymmetry of Impact Analysis, 7 THEORY AND PRAC. LEGIS. 227, 229, 249 (2019).

251 Exec. Order No. 12,866, § 1(b)(3), 58 Fed. Reg. 51,735 (Sept. 30, 1993).

252 See Ellig \& Horney, supra note 250, at 232. 
model. That may, in turn, help explain what could be OIRA's lack of enthusiasm for using its limited resources to provide such technical assistance.

\section{Internal Revenue Service MOA}

Until recently, OIRA review-distinct from OIRA technical assistancehas been framed as an all-or-nothing choice. But in April 2018, the U.S. Department of Treasury and OMB signed an MOA ${ }^{253}$ that signals new flexibility. The 2018 MOA expanded the scope of IRS regulatory actions that would come in to OIRA for review prior to publication. ${ }^{254}$ IRS is not an independent regulatory agency but it had been able to function like one for most of its regulations. ${ }^{255}$ An MOA from 1983, ratified in 1993, limited the type of actions that would fall under OIRA review. ${ }^{256}$ In 2017, EO 13,789 directed Treasury and OMB to "review and, if appropriate, reconsider the scope and implementation of the existing exemption for certain tax regulations from the review process set forth in Executive Order 12866 and any successor order."257

The result of that negotiation was a new MOA that negotiated not just the types of actions that would be subject to OIRA review, but other critical terms as well. ${ }^{258}$ This included how long review would take, including assurance that OIRA would review some actions more quickly than the EO 12,866 timeframe of ninety days; analytical issues such as how to measure certain thresholds for review; a phase-in period; and dispute resolution procedures. ${ }^{259}$ The MOA terms signal that OIRA might be open to negotiating the terms of its review beyond what was previously understood to be negotiable. Former OIRA Administrator Neomi Rao acknowledged the flexibility in remarks shortly after she signed the MOA: "The basic structure [of the agreement] follows the regular OIRA centralized review process. However, we have provided for shorter time frames for review, particularly for certain tax reform rules, and we've also included provisions that account for the unique revenue-raising function of Treasury." 260

Rather than OIRA review as a one-size-fits-all proposition, the IRS MOA shows willingness to negotiate on meaningful terms. Compared to the CFTC MOU, in which CFTC holds OIRA at arm's length and stops short of full OIRA review, the IRS MOA applies OIRA review with what can be viewed as some

253 Memorandum OF AGREEMENT, supra note 1, at 3.

254 Dooling, supra note 227, at 230-31.

255 Id. at 232 n.66.

256 Memorandum of AgreEment, TREASURy AND OMB, IMPLEMENTATION OF EXECUTIVE ORDER 12,291 (Apr. 29, 1983), https://www.treasury.gov/FOIA/Documents/ OMB\%20MOA\%2083-93.pdf [https://perma.cc/C92M-CRG2].

257 Exec. Order No. 13,789, § 2(c), 82 Fed. Reg. 19,317 (Apr. 21, 2017).

258 Dooling, supra note 227, at 229-34.

259 Id. 17:38).

260 Opening Address, supra note 229 (discussing independent agencies at 17:24- 
concessions on OIRA's part. This is critical new information for independent regulatory agencies.

Signaling the relevance of this approach to the independent regulatory agencies, then-Administrator Rao noted: "[B]eyond the specifics this new MOA recognizes the importance of the principle of centralized regulatory review even in a context such as tax. These broader principles could also be extended to the traditionally-understood independent agencies."261

\section{B. Potential Independent Regulatory Agency MOA Provisions}

If an independent regulatory agency might consider some form of OIRA review as a way to improve its analysis, it might seek several types of provisions in a MOA. This could include dispute resolution, phase-in, technical assistance, review timing, disclosure provisions, and more. This section sketches some potential terms and starts with the issue of political control.

\section{Political Control}

The issue of political control of decision-making is a threshold matter because it is likely critical to an independent regulatory agency's calculation of whether to negotiate with OIRA. It should also inform whether the president directs OIRA to negotiate. To enter into negotiation, both parties may need to disarm somewhat. The president may need to set aside the rhetoric of the unitary executive, and the independent regulatory agency may need to set aside the rhetoric of the "constitutional force field" 262 described above. How else could they justify the negotiation? This does not require either party to fully abandon these ideas, but to soften their respective postures for the sake of negotiation. ${ }^{263}$

Ultimately, the strength of an agency's manifest independence vis à vis executive power will likely determine how any possible agreements are structured. For agencies with a weaker claim to independence, submitting to some form of OIRA review does not seem to be an improper erosion of their independence. Rather, it corrects for the error of over-extending independence. These weaker agencies might be willing to enter into negotiation now because of the specter of Supreme Court decisions that could undermine their independence. ${ }^{264}$ Agencies with a stronger claim to independence will likely be able to fend off a stronger form of OIRA review. ${ }^{265}$

261 Id. (discussing the importance of the principle of centralized regulatory review at 17:40-17:57).

262 See supra note 121 and accompanying text.

263 This may very well be a non-starter for some, but it is arguably the hardening of these two postures that has left the issue of OIRA review of independent regulatory agencies at a stalemate.

264 See generally, e.g., Seila Law LLC v. Consumer Fin. Prot. Bureau, 140 S. Ct. 2183 (2020).

265 See Exec. Order No. 12,866, § 6(a)(3), 58 Fed. Reg. 51,735 (Sept. 30, 1993). 
For the president and OIRA, perhaps the biggest question is whether they could or should negotiate away aspects of White House political oversight that accompanies its review of other agency rules. Supporters of the unitary executive theory might reflexively say no, but the status quo of exempting these agencies suggests the political limits of that theory. Consider the IRS MOA as an example. IRS sits within a cabinet agency, ${ }^{266}$ and yet OIRA negotiated with them. ${ }^{267}$ What accounts for that behavior, if the executive's power is complete? The flexibility OIRA revealed in the MOA stands in sharp relief to its common portrayal as a powerful, if not omnipotent, office. ${ }^{268}$ The IRS MOA is evidence that this portrayal is likely more caricature than is currently appreciated, reflecting that OIRA's political power with respect to any particular decision is generally subject to countervailing political forces. ${ }^{269}$ Contrary to the caricature, OIRA, an agent of the president, might not be able to impose its will without giving up something in return. ${ }^{270}$

This article has already explained that the threat of judicial review may encourage independent regulatory agencies to see some form of OIRA review. OIRA, on the other hand, might be willing to negotiate in service to at least two goals. One goal is greater political oversight of particular regulatory actions on behalf of the president, which is facilitated by OIRA review. ${ }^{271}$ An important second goal is improved regulatory decision-making as a result of interagency coordination on overlapping policy areas as well as the use of regulatory analysis techniques including, but not limited to, cost-benefit analysis. The latter goal is perhaps more easily understood as a "good government" objective though many, including Kagan, would argue that strong presidential control of agency action is good for government as well. ${ }^{272}$ Nevertheless, cleaving a distinction between these two general goals is critical to understanding why OIRA might be willing to trade these goals off in a negotiation. It is unclear that they would, but the flexibility in the IRS MOA at least suggests the possibility that they could.

There is also the possibility that the negotiation is not a zero-sum game. Michael Livermore argues that dexterity with cost-benefit analysis itself can give an agency some insulation from political control. ${ }^{273}$ If that is correct,

266 Bureaus, U.S. DEP'T TREASURY, https://home.treasury.gov/about/bureaus [https://perma.cc/BXB5-KH65].

267 See MEMORANDUM OF AGREEMENT, supra note 1 , at 1.

268 See id.

269 See Dooling, supra note 227, at 235.

270 See id.

271 See id.

272 Kagan, supra note 3, at 2252 ("I aver that in comparison with other forms of control, the new presidentialization of administration renders the bureaucratic sphere more transparent and responsive to the public, while also better promoting important kinds of regulatory competence and dynamism.").

273 Michael A. Livermore, Cost-Benefit Analysis and Agency Independence, 81 U. CHI. L. REV. 609, 611-12 (2014) (arguing that agency influence over the methods and details of cost-benefit analysis can limit its usefulness as an instrument of political control). 
acceptance of some form of OIRA review need not imply political surrender for an independent regulatory agency.

\section{Dispute Resolution}

Turning to specific provisions, an MOA could establish proper channels of communication, anticipate disagreements, and specify one or more elevation points for resolution. ${ }^{274}$ If the agency does not have formal positions until after its commissioners vote, an MOA could specify whether someone at the agency, such as its chair or executive director, is empowered to oversee OIRA review on its behalf prior to a vote, or whether the agency would need a formal vote prior to a draft being sent to OIRA for review. These are nuances that will be unique to each agency's authorities, structure, and culture, and they lend themselves to bilateral, as opposed to blanket, policymaking.

For dispute resolution, staff could elevate issues to OIRA's Deputy Administrator ${ }^{275}$ and his appropriate counterpart at the independent regulatory agency, and then to the OIRA Administrator and her appropriate counterpart, if needed. The agreement would ideally specify OIRA's appropriate counterparts at the agency, such as the executive director, chief economist, chief of staff, or chairman, to provide an explicit pathway to resolving disputes.

Parties might find that creating a series of elevation points allows them to compromise on issues rather than immediately calling the constitutional question of whether the president can require the independent regulatory agency to follow his direction. If that does not resolve the issue, however, particularly for an agency with a stronger claim to independence, a term could be included to allow OIRA to stand down and file a comment in the agency's public docket detailing any remaining concerns. This is just one configuration that could be used to recognize independence where it exists, but there are likely others that could emerge through negotiation. Adding process steps in this general manner, however, could give both parties the opportunity to reap the benefits of productive conflict ${ }^{276}$ while still offering a way out.

\section{Phase-Ins and Technical Assistance}

Another practical concern independent regulatory agencies might have about OIRA review is the question of relevant resources and expertise. They might be concerned that OIRA lacks staff and expertise in the legal authorities, procedures, and policy approaches underpinning the agency's work. This was a

${ }^{274} C f$. Kagan, supra note 3, at 2288-90 (discussing the merits of a formal dispute resolution policy).

275 This is the top career official in OIRA. SUBCOMM. ON COM. AND ADMIN. L., 109TH CONG., INTERIM REPORT ON THE AdMINISTRATIVE LAW, PROCESS AND PROCEDURE PROJECT FOR THE 21ST CENTURY 1255 (Comm. Print 10).

276 See Farber \& O'Connell, supra note 134, at 1385 ("[C]onflict plays an important and often productive role in the functioning of the modern administrative state."). 
concern with the IRS MOA. ${ }^{277}$ An agency might be concerned about its own lack of expertise with the economic principles and analytical framework that OIRA uses for regulatory analysis. ${ }^{278} \mathrm{~A}$ term allowing for a phase-in, like the one in the IRS MOA, ${ }^{279}$ could help smooth the transition and ramp up expectations over time. This would allow both parties to hire and train additional staff, if needed, and assuming adequate resources to do so. ${ }^{280}$ Parties could also consider a term about mutual technical assistance, perhaps including periodic staff rotations between OIRA and the agency.

\section{Review Process}

The parties could also negotiate the review process. The number of days for review, negotiated in the IRS MOA, is a good example. ${ }^{281}$ Parties could also agree to use a "chess clock" to handle the way days are counted, to discourage either side from running the clock during review. Or break it into phases of review with different time periods. Beyond the duration of review, parties could negotiate at what point OIRA review takes place consistent with the workflows (e.g., voting procedures) of the independent regulatory agency.

\section{Transparency}

Another term that could be helpful is one that reconciles the various information disclosure requirements that apply to regulatory review. OIRA has disclosure requirements under EO $12,866^{282}$ and it otherwise relies on the deliberative process privilege to promote candor by cloaking its interagency work. $^{283}$ Independent regulatory agencies, however, are generally subject to the

277 See, e.g., Eileen J. O'Connor, Excessive Review of IRS Regulation Delays Needed Government Revenue, HILL (Apr. 12, 2018), https://thehill.com/opinion/finance/382725excessive-review-of-irs-laws-delays-needed-government-revenue [https://perma.cc/V7N6$8 \mathrm{KVN}]$. But see Marie Sapirie, The IRS and OMB Seem To Get Along In The Tax Reg Review Process, FORBES (Jan. 22, 2020), https://www.forbes.com/sites/taxnotes/2020/01/22/the-irsand-omb-seem-to-get-along-in-the-tax-reg-review-process/\#614f4fe527a4 [https://perma.cc/ $876 \mathrm{Y}-\mathrm{JNAZ}]$ (“[T]he process is now proceeding according to plan and not posing much of an obstacle to the prompt release of regulations.").

278 See, e.g., OfFICE OF MGMT. AND Budget, EXEC. OfFICE OF THE PRESIDENT, OMB Circular No. A-4, at 7 (Sept. 2003) [hereinafter OMB Circular No. A-4].

279 See MEMORANDUM OF AGREEMENT, supra note 1, at 3.

280 This is a rather big assumption. Agency budgets, including OIRA's are often constrained. One assurance OIRA might try to seek, in exchange for taking on these negotiations, is the promise of sufficient resources over time. See Conti-Brown, supra note 74 , at 273 (2015) ("The power of the purse is one of the primary means of Congressional control over agencies.").

281 MEMORANDUM OF AGREEMENT, supra note 1, at 1-2.

282 Exec. Order No. 12,866, § 6(b)(4), 58 Fed. Reg. 51,735 (Sept. 30, 1993).

283 See generally Gbemende E. Johnson, Adjudicating Executive Privilege: Federal Administrative Agencies and Deliberative Process Privilege Claims in U.S. District Courts, 53 L. \& SOC'Y REV. 823 (2019). 
Sunshine Act, ${ }^{284}$ which, as discussed above, is somewhat in tension with the deliberative process privilege depending on how review is conducted. The CFTC MOU handled this with a term that asserted that the MOU did not disrupt any lawful privilege or confidentiality. ${ }^{285}$ In areas where materials covered by the Sunshine Act and the deliberative process privilege seem to overlap, e.g., written materials sent from OIRA to the independent regulatory agency's commissioners, a more specific MOA term could help set expectations on both sides, as well as for the public.

Although this section has offered some examples of terms that the parties could negotiate, there are surely more, such as the scope of review (e.g., what types of actions would be reviewed), level of analytical rigor for different levels or types of actions, evaluation periods, renegotiation timeframes, exit clauses, sunsets, and limits on judicial review. The MOAs could be customized to cover what the parties need, which does not necessarily need to be lengthy. The CFTC MOU was only one page. ${ }^{286}$ The 2018 OMB-Treasury MOA was three pages, ${ }^{287}$ reflecting greater complexity of the arrangement.

While they are unlikely to be legally binding on the parties in a manner enforceable in court, MOAs are a way for agencies to document and commit to mutual understanding. ${ }^{288}$ Both parties to an MOA can benefit from that certainty as they navigate new ways of working together.

An open and pressing question is which terms the parties would willingly endure to secure the benefits of increased review. As proposed here, the president would not attempt to use presidential action to force the agencies to the table with OIRA. ${ }^{289}$ Rather, the president could instruct OIRA, formally through an executive order or presidential memorandum or informally through other instructions to the OIRA Administrator, to contact one or more agencies to begin negotiations. If, in the course of meetings, OIRA is able to make a good enough case for some form of collaboration, this might lead to an agreement. The risk in any genuine negotiation is that it will not result in agreement. Allowing the parties to walk away is a way to ensure that they retain what is essential about each of them.

\section{Considerations}

The use of bilateral MOAs to subject independent regulatory agencies to some form of regulatory review, a concept that this paper is calling bespoke regulatory review, has several policy considerations.

284 The Government in the Sunshine Act, 5 U.S.C. § 552b(a)(1) (1976).

285 MEMORANDUM OF UNDERSTANDING, supra note 232.

286 Id.

287 MEMORANDUM OF AgREEMENT, supra note 1.

288 Farber \& O'Connell, supra note 134, at 1410.

289 Others might prefer more direct and controlling action on the president's part because they are skeptical of any claims to independence on the part of these agencies. $C f$. $i d$. at 1411. 
First, there may be other ways to get independent regulatory agencies the technical expertise they need to prepare higher-quality regulatory analyses. One idea is that the independent regulatory agencies could pool their resources to stand up, or request that Congress create, an OIRA-like office that services many agencies. ${ }^{290}$ One might argue such an approach avoids political control described above and creates constructive analytical competition between OIRA and an OIRA-like entity that might be salutary for regulatory analysis as a whole.

Kagan considered such a possibility of "a less political kind of central institution," concluding that it would "slight the... important norm of democratic accountability." 291 It also fails to anticipate the value of the "real push from the political system" that she describes as not merely tolerable, but essential. ${ }^{292}$

With regard to analytical competition, an important clarification is that OIRA review does not exist to ensure uniformity of agency analysis. Instead, OIRA review can balance analytical rigor against the particulars of statutory requirements and other practical considerations, such as the state of the evidence relevant to the regulatory issue at stake. For example, the analysis for a brandnew regulation is likely to be highly speculative, ${ }^{293}$ and should contain caveats that make that transparent, while an incremental change to a long-lived regulation should be able to draw upon more evidence. With a few exceptions set out in Circular A-4, agencies reviewed by OIRA enjoy flexibility on analytical approaches, and that allows for analytical innovation. ${ }^{294}$

Also, OIRA is able to convene dialogues across the federal government, often with outcomes and approaches that are unique. It is these coordination benefits that tend to be underappreciated. ${ }^{295}$ Agencies, "if left to their own devices, would focus on their own missions without devoting sufficient attention to government-wide priorities." 296 While this may seem like exactly the reason Congress gave them independent features, it can lead to inadequate coordination across agencies working in similar areas. ${ }^{297}$ For these reasons, a separate OIRAlike office is not a superior choice.

290 E.g., Rose-Ackerman, supra note 127, at 340 (citing STEPHEN BREYER, BREAKING THE Vicious Circle: Toward EFFECTIVE Risk REgulation 55-81 (1993) and Bruce Ackerman, The New Separation of Powers, 113 HARV. L. REV. 633, 688-714 (2000)).

291 Kagan, supra note 3, at 2340.

292 Id. at 2341.

293 See OMB CirCULAR No. A-4, supra note 277, at 27.

294 Id. at 7 ("There must be some balance between thoroughness and the practical limits on your analytical capacity. With this qualification in mind, you should nevertheless explore modifications of some or all of a regulation's attributes or provisions to identify appropriate alternatives.").

295 See Sunstein, supra note 125 , at 1840.

296 Bressman \& Thompson, supra note 87, at 621.

297 See id. (citing STEPHEN BREYER, BREAKING THE ViCIOUS CYClE: TOWARD EFFECTIVE RISK REGULATION 80 (1993) on the need for "increased coordination and rationalization" among agencies). 
Second, bespoke regulatory review rationalizes the currently uneven application of economic analysis to draft regulatory actions. Coglianese calls this type of analysis an opportunity for regulators to "look before they leap."298 Many have noted the practical limitations of economic analysis in the regulatory context. 299 While it undoubtedly needs improvement, the alternativeregulatory analysis that willfully ignores what economics can tell us about costs, benefits, incentives, and unintended consequences - is not an acceptable path. Although it had a controversial start, requiring agencies to conduct economic analysis of regulations has been U.S. regulatory policy since the $1980 \mathrm{~s} .{ }^{300}$ Even if one objects to OIRA's political role, there is no reason to exclude independent regulatory agencies from this type of analysis categorically. 301

Third, this approach offers independent regulatory agencies more ready access to another tool to address defects in regulatory analysis that lead to remand upon judicial review. Conducting economic analysis in a manner consistent with other agencies, and having OIRA review that analysis is a way to bolster analysis and protect it more successfully from remand. Although it will take agency resources to conduct this analysis, there are at least some offsetting savings to be had as a result of fewer remanded or vacated rules.

Fourth, it offers a way to resolve a long-running stalemate between the president and the independent regulatory agencies, in a way that largely sidesteps challenging legal and political questions and accounts for practical difficulties. Datla and Revesz suggest as an alternative to the flawed, binary view of agency independence: "[T] he President can constitutionally take any action with respect to independent agencies that he could with respect to the executive agencies unless a statutory provision says otherwise." 302 But in the realpolitik of agency independence, that action may need to entail political restraint on the part of the president, particularly for those independent regulatory agencies with stronger claims to their independence. And, as shown in both the CFTC and the IRS examples, the president need not personally intervene to extend OIRA's review to parts of the executive. In the case of IRS, the president tasked the parties with working out an arrangement. ${ }^{303}$ In the case of CFTC, the parties appear to have negotiated of their own volition. ${ }^{304}$ Under an MOA with an independent regulatory agency, the president can acknowledge the relative independence of these agencies while still taking steps to improve regulatory policy.

298 Coglianese, supra note 130, at 741. But see Nicholas Bagley, The Procedure Fetish, 118 MicH. L. REV. 345, 401 (2019) (“Administrative law could achieve more by doing less.").

299 E.g., OMB CIRCULAR No. A-4, supra note 277, at 10-14.

300 Rose-Ackerman, supra note 127, at 335.

301 E.g., id. at 337-38 (arguing in favor of "technocratic analysis" despite reservations about OIRA).

302 Datla \& Revesz, supra note 75 , at 774.

303 MEMORANDUM OF AGREEMENT, supra note 1.

304 MEMORANDUM OF UNDERSTANDING, supra note 232. 
This proposal also relies on the independent regulatory agency's willingness to enter into an MOA. All agency heads, not just ones thought to be independent, have options in the face of presidential overtures and directives. ${ }^{305}$ They can willingly come to the table, or they can resist in a variety of ways, including public statements of disagreement. ${ }^{306}$ The political will theory described earlier suggests that an agency with a greater claim to independence will likely be able to resist strong forms of political review. A president, in turn, would have to choose whether and how to proceed: "[T] to bring the agency around to his view. Whether presidents do so will depend on how much political capital they are willing to spend rather than how the agency is categorized." 307 All of these factors inform whether a negotiation would take place in the first instance, and result in agreement in the second instance. ${ }^{308}$

Fifth, presidential action to bring the independent regulatory agencies under OIRA review without accommodations for their independence would likely be viewed as aggressive and a "major shift in the norms and practices of autonomous regulatory decision making that have long prevailed at independent agencies." 309 It would likely provoke Congressional backlash and legislation or other oversight activity that aims to restore the prior balance. ${ }^{310}$ As Alan Morrison put it:

[E]ven raising that question [of agency independence] is likely to cause a furor on Capitol Hill, for few ideas seem to offend members of the two Commerce committees more than suggesting that independents should be abolished ... it is surely a fact of political life that any such efforts would be met with substantial resistance. ${ }^{311}$

Datla and Revesz also acknowledge this dynamic, noting that if the president directed the independent agencies to comply with OIRA review, "Congress can of course exempt agencies from the regulatory review requirement, just as it has done in response to previous presidential assertions

305 See Datla \& Revesz, supra note 75 , at 842.

306 Id.

307 Id.

308 A related concern is whether OIRA can be a good and reliable negotiating partner, or whether it will expand its reach in the course of working with an agency. Peter Shane has vividly questioned whether, under this article's proposal, agencies are like Hansel \& Gretel receiving an invitation to visit a certain gingerbread house. See generally JACOB GRIMM \& WilHelm GRIMM, THE ORIGINAL FolK AND FAIRY TALES OF THE BROTHERS GRIMM: THE COMPLETE FIRST EDITION (Jack Zipes trans. \& ed., Princeton University Press 2014) (1812). Email from Peter Shane, Professor, The Ohio State Univ. Moritz Coll. of Law, to author (Aug. 10, 2020) (on file with the Ohio State Law Journal). This is a fine question. Worry about this could possibly be addressed with an exit clause in the agreement.

${ }^{309}$ Coglianese, supra note 130, at 748 .

310 See Katzen, supra note 171, at 109-10 ("[S]ome may see this as a power play for OIRA.”).

${ }^{311}$ Morrison, supra note 99, at 255. 
of control over the administrative state." 312 An aggressive, uniform action is more likely to provoke a response. ${ }^{313}$ Negotiation, however, has a lighter touch. It is harder to argue that it is a form of aggression if the independent regulatory agency agrees to it.

Sixth, negotiation takes time and other resources. There are more than a dozen independent regulatory agencies. ${ }^{314}$ It took Treasury and OMB almost one year from the date of EO 13,789 to the date of the IRS MOA. ${ }^{315}$ One year per negotiation might be too low of an estimate because IRS does not present the complexities of an independent regulatory agency, but if OIRA took on one negotiation per year that would be almost two decades before these negotiations were completed. Of course, OIRA could take on more than one negotiation at a time. But as a small agency of roughly fifty people, OIRA could get overwhelmed if it tries to move too fast. An advantage of an incremental MOA process is that it allows for "managerial innovation" 316 in negotiating tactics and potential terms along the way, as well as requests for additional resources as needed.

This is not an exhaustive list, but even this sketch suggests that there are many considerations that will ultimately play into any decision to extend bespoke regulatory review to independent regulatory agencies. This article offers this proposal, potential terms, and some considerations to shine light on a potential pathway, even if its exact contours are uncertain.

\section{CONCLUSION}

This article has shown that the rise in judicial review of agency regulatory analysis poses acute risks for the independent regulatory agencies, which are not subject to OIRA review. These agencies are isolated from OIRA due, in part, to a misunderstanding about the nature of agency independence; it is far more complex than is widely appreciated. Until recently, regulatory review under EO 12,866 was considered to be a one-size-fits-all set of procedures, but new agreements negotiated by OIRA show that it is not. Bespoke regulatory review is an alternative way of conceptualizing OIRA review. It allows independent regulatory agencies to negotiate with OIRA towards regulatory review terms that are mutually beneficial. The ultimate beneficiary, though, is the public, which will benefit from regulatory decisions informed by better regulatory analysis.

312 Datla \& Revesz, supra note 75 , at 775.

313 Id. at 837 (explaining that including independent agencies in regulatory review "risks provoking a fight with Congress over control of these agencies").

314 See Other Federal Agencies, supra note 191.

315 Compare Exec. Order No. 13,789, 82 Fed. Reg. 19,317 (Apr. 21, 2017), with MEMORANDUM OF AGREEMENT, supra note 1 (dated April 11, 2018).

316 Datla \& Revesz, supra note 75, at 842; accord Kagan, supra note 3, 2281-82, 2293 (discussing innovations of Presidents Clinton and Bush). A related point is that all agencies, including those without independent features, could request formal bespoke agreements. Even if the president ultimately backs OIRA up, it could result in an avalanche of requests that OIRA would have to respond to, burning political capital as agencies argue for special terms and carve-outs from OIRA review. 
